\title{
A New Generation of Drugs: Synthetic Peptides Based on Natural Regulatory Peptides
}

\author{
Timur Kolomin $^{1 *}$, Maria Shadrina ${ }^{1}$, Petr Slominsky $^{1}$, Svetlana Limborska ${ }^{1}$, Nikolay Myasoedov ${ }^{2}$ \\ ${ }^{1}$ Department of Molecular Basis of Human Genetics, Institute of Molecular Genetics Russian Academy of Sciences, Moscow, Russia; \\ ${ }^{2}$ Department of Chemistry of Physiologically Active Compounds, Institute of Molecular Genetics Russian Academy of Sciences, \\ Moscow, Russia. \\ Email: *kotimur@img.ras.ru
}

Received July $15^{\text {th }}, 2013$; revised August $13^{\text {th }}, 2013$; accepted September $10^{\text {th }}, 2013$

Copyright (C) 2013 Timur Kolomin et al. This is an open access article distributed under the Creative Commons Attribution License, which permits unrestricted use, distribution, and reproduction in any medium, provided the original work is properly cited.

\begin{abstract}
Natural regulatory peptides are biologically active compounds that are produced by various cells and provide a link among the main regulatory systems of the body. The field of research into the biologic activity of endogenous regulatory peptides is extremely vast. These peptides affect the cardiovascular, immune, reproductive, endocrine, digestive, and other systems, alter energy metabolism, and are especially effective in the regulation of the central nervous system. Despite of the wide range of preventive and therapeutic effects of natural regulatory peptides and proteins, their application in clinical practice is difficult. This is primarily because of their extreme instability, as they are rapidly degraded by proteases of the gastrointestinal tract, blood, cerebrospinal fluid, and other biologic media. Compounds with higher stability (i.e., a considerably longer half-life compared with that of natural molecules) and the ability to provide a directional effect on the various body systems were obtained from modifications of endogenous regulatory peptides. Synthetic analogs of regulatory peptides, as a rule, contain only natural amino acids in their composition, and their biodegradation does not lead to the formation of toxic products; thus, they have fewer side effects. This review focuses on the consideration of two synthetic regulatory peptides, Semax and Selank, which were the bases for the creation of new drugs that are used effectively in the treatment of various diseases of the nervous system. The synthetic analog of an adrenocorticotropic hormone $4-10$ fragment $\left(\mathrm{ACTH}_{4-10}\right)$ Semax is a powerful neuroprotective agent that is particularly effective as a therapy for stroke. Selank was synthesized on the basis of the natural immunomodulator tuftsin. Selank is a powerful anxiolytic that is used as a therapy for generalized anxiety disorder and neurasthenia without sedative and muscle-relaxant effects. This review presents the results of research aimed at studying the influence of these peptides on the transcriptome of brain cells. The problems of drugs developed based on the clinical activities of Semax and Selank are discussed separately.
\end{abstract}

Keywords: Semax; Selank; Regulatory Peptides; ACTH; Tuftsin; Neuroprotection; Nootropes; Anxiolytics

\section{Introduction}

The development and investigation of novel neurotropic drugs seem to be a challenging scientific problem for modern biology and pharmacology. Effective and safe pharmacological remedies that stimulate the cognitive functions of the brain and are neuroprotective in different pathologies of the central nervous system are needed urgently. The use of endogenous regulators of the body, especially regulatory peptides, as a basis for the development of drugs that meet the requirements stated above provides one of the most promising directions for this

${ }^{*}$ Corresponding author. type of research. Peptide substances have been shown to be the direct regulators or mediators of the majority of physiological processes that occur in the body. In addition, regulatory peptides exhibit a vast range of biologic activities.

Neuropeptides represent important regulators of the central nervous system. However, the study of the biologic properties and mechanisms of action of the major known neuropeptides revealed that the clinical application of the full-size molecules of these compounds was extremely complicated because of their instability inside the body and the fugacity of their effects. In this context, it becomes necessary to use them as a basis of the de- 
velopment of more stable synthetic molecules by various modifications, which might be more effective compared with their prototypes, and at the same time, less harmful for use in clinical settings.

The aim of this review is to consider the characteristics of two new-generation peptide preparations: the synthetic analog of an adrenocorticotropic hormone 4 - 10 fragment $\left(\mathrm{ACTH}_{4-10}\right)$, the neuroprotector and nootrope Semax, and the natural immunopeptide tuftsin analog, the anxiolytic and nootrope Selank. Large-scale studies of the range of biologic activity and mechanism of action of Semax and Selank revealed that the therapeutic potential of drugs derived from these compounds was far from being exhausted, and that new indications for their application could be discovered.

Success in the creation of drugs based on the synthetic peptides Semax and Selank and the achievement of positive outcomes from their clinical applications required the study of their mechanisms of action, as this opens new approaches to the creation of pharmacologically important molecules and reveals the impact of new targets for the directed regulation of cellular functions in health and disease.

\section{Natural and Synthetic Regulatory Peptides}

Regulatory peptides are universal endogenous biologic regulators of cellular functions in the body. They are part of the most complicated system of specialized signaling molecules, of which the principal function is the integration of the nervous, endocrine, and immune systems to form a united functional continuum.

Extensive investigation of regulatory peptides began in the 1970s after a team of Dutch researchers headed by David de Wied demonstrated that the adrenocorticotropic hormone and its fragments affected the learning of animals [1]. Currently, over 9000 regulatory peptides that differ in both structure and properties have been described, the majority of which contain from 2 to 50 amino acid residues and belong to the group of oligopeptides with no more than 20 amino acids or to the group of polypeptides with 20 to 100 amino acid residues.

Posttranslational processing is one of the main pathways of regulatory-peptide formation in the body, via which they are isolated from the physiologically inactive precursor proteins with the help of specialized enzymesproteases. In some cases, a single precursor protein gives rise to a whole group of peptides, which are required for the successful accommodation of the body to various well-definite changes in the environment. This type of pathway is the most effective way to achieve this goal and provides a practically immediate release of the amount of regulatory peptides required by the body. Moreover, the processed peptides have a far shorter half- life compared with that of their precursor proteins, which is a significant precondition for the rapid interruption of the signal processes mediated by these molecules, in case they become unnecessary [2].

The mechanism of action of regulatory peptides in a target cell is conditioned by their binding to special membrane receptors. All regulatory peptides are pleiotropic and are able to influence a number of physiological functions, with individual functions being simultaneously regulated by several peptides. The fact that regulatory peptides that affect target cells are able to regulate the release of other regulatory peptides, which, in turn, initiate the generation of a new wave of regulatory peptides, represents an important feature of their mechanism of action. This allowed Ashmarin et al. to pinpoint the existence of cascade processes in the regulatory peptide system that sustain the effect of a single administration of a peptide for a considerable period (up to several days), whereas the half-life of the peptide does not exceed several minutes. This sets forth the functional continuum of regulatory peptides that participate in the transfer of information among the systems of the body (its organs, tissues, cell groups, and individual cells), thereby regulating their activity and integrating their performance into a unity. Thus, the regulatory-peptide system is involved in the regulation of virtually all physiological responses of the body, and maintains the homeostasis of all of its systems [3-6].

All cells of the body permanently synthesize, and support the required levels of, regulatory peptides. However, their biosynthesis undergoes changes in the presence of broken homeostasis. A similar instability occurs during adaptive responses to the background of physical or/and emotional strain, predisease conditions, etc., thereby preventing the disturbance of the functional balance, which is an indication that the regulation of the metabolism of endogenous peptides occurs at the cellular level (transcription, translation, and posttranslation processing), at the tissue level (secretion and inactivation of regulatory peptides), and at the level of the body as a whole [7].

The classification of regulatory peptides takes into account their chemical and physiological structure and their origin. One of the main difficulties in classifying these molecules lies in their multifunctional character, which does not allow one or even several functions to be established in a substrate. Considering the physiological and biochemical properties of regulatory peptides, previous studies have suggested a three-group classification [8]:

- Class I regulatory peptides exert a distant effect and have high affinity for receptors; in addition, their principal characteristics render them similar to oligopeptide hormones, such as vasopressin, oxytocin, somatostatin, and endogenous opiates. 
- Class II regulatory peptides exert a distant effect and have relatively low affinity for receptors. They are synthesized from nonspecific proteins (collagen and elastin). Glyprolines and enterostatins, for example, belong to this class.

- Class III regulatory peptides comprise peptides that act locally, at the level of organs and tissues (e.g., neurotrophins).

Numerous studies on the biologic properties and mechanisms of action of endogenous regulatory peptides suggested the potential application of peptide regulators in clinical settings. However, regardless of their preventive and therapeutic action, the use of peptide regulators as medicinal drugs appeared extremely difficult, primarily because of their multifunctional nature and high instability. After introduction into the body, regulatory peptides undergo rapid splitting by the proteases of the alimentary tract, blood, cerebrospinal fluid, and other biologic media. Therefore, the desired effects of regulatory peptides introduced into the body are transient and limited [9].

Thus, the search for methods to enhance the efficiency and duration of the effect of regulatory peptides became the main task of researchers in this field. Among the numerous attempts undertaken to solve this problem, the replacement of natural left-handed amino acids in the regulatory peptide molecule by D-isomers or even organic radicals was one of the main approaches used in the creation of synthetic analogs of endogenous regulators. In the majority of cases, this method caused a considerable increase in the resistance of the compounds obtained to protease action. Nevertheless, the addition of non-natural components to natural molecules resulted in negative side effects for the synthetic analogs [10].

The inclusion in the structure of the natural molecules of amino acid sequences that are resistant to peptidases was another approach that was used to solve this problem. The introduction of proline-residue-enriched regions into natural molecules represented an alternative approach. It is common knowledge that the organs and tissues of the majority of hematothermal animals bear a variety of low-specificity exo- and endopeptidases that do not break AA-Pro bonds, in which AA is any amino acid followed by sequences rich in proline residues. Small amounts of specific proline-hydroxylases accumulate mainly in individual organs and tissues. Based on this fact, it was hypothesized that the attachment of proline-carrying sequences to the C-terminal region of natural molecules would elicit a prolonged action and a stronger effect compared with those of the natural entity [11].

Members of the glyproline family were the most effective among the proline-carrying sequences used in the modification of natural regulatory peptides. Glyprolines are oligopeptides that are formed during the degradation of collagen and elastin, and contain glycine and proline (Gly-Pro, Pro-Gly, Pro-Gly-Pro, etc.). Glyprolines are extremely stable, and protect the sequences added to them against cleavage by the proteases of the body [12, 13].

A number of synthetic medical preparations based on natural regulatory peptides have been developed by a research team headed by Drs N.F. Myasoedov and I.P. Ashmarin using the approach described above. Among them, the two most promising peptide drugs, Semax and Selank, deserve special attention.

Semax (H-Met-Glu-His-Phe-Pro-Gly-Pro-OH) is a synthetic analog of the adrenocorticotropic hormone 4 10 fragment $\left(\mathrm{ACTH}_{4-10}\right)$. It exhibits distinct neuroprotective and nootropic properties and is the basis for a number of drugs that are used in clinical practice for the treatment of CNS diseases (ischemic brain stroke, dyscirculatory encephalopathy, optic nerve atrophy, etc.) and to enhance adaptability under extreme conditions in healthy persons.

Selank (H-Thr-Lys-Pro-Arg-Pro-Gly-Pro-OH) is a synthetic analog of the short fragment of the human immunoglobulin $G$ heavy chain (tuftsin). It exhibits antianxiety and nootropic effects. A drug based on Selank is used in therapy for generalized anxiety disorders and neurasthenia and to enhance adaptability under extreme conditions in healthy persons.

Despite the fact that all drugs developed from these peptides have passed all preclinical and clinical tests and are successfully used in clinical practice, the range of their physiological activity and their mechanisms of action in the body have not been studied fully and largescale research on these peptides is still in progress.

\section{Semax Is a New-Generation Neuroprotective and Nootropic Compound}

\subsection{Background}

The adrenocorticotropic hormone (ACTH) and its fragments represent one of the most actively studied classes of endogenous regulatory peptides. ACTH is a singlechain polypeptide consisting of 39 amino acids that is formed in the glandular lobe of the anterior lobe of the hypophysis via posttranslational processing of the precursor protein proopiomelanocortin (POMC) [14,15].

The main function of ACTH is associated with steroidogenesis. After binding to the melanocortin 2 (MC2) receptor on the plasma membranes of cortical cells of the suprarenal gland, corticotropin enhances the synthesis and secretion of glucocorticoids and intensifies the transformation of cholesterol to pregnenolone. The $24 \mathrm{~N}$-terminal amino acids of ACTH are required to attain the full manifestation of the biologic activity of this hormone 
[16].

ACTH is one of the main regulatory components of the pituitary-hypothalamic axis, and interacts with other peptide hormones (prolactin, vasopressin, thyroliberin, the vasointestinal peptide, opioid peptides, etc.) and with the mediatory systems of the hypothalamus [7]. In addition to its hormonal effect, ACTH displays a broad range of extrahormonal activities. For instance, multiple studies have shown that ACTH and its fragments affect human and animal behavior. The first evidence of the effect of ACTH on the behavior of animals was obtained in the mid-1950s [17,18]. At that time, David de Wied and colleagues studied the influence of ACTH and its fragments on the learning abilities of animals and showed that the removal of the glandular lobe of the hypophysis results in disturbed formation of conditioned responses. ACTH administration to hypophysis-ectomized animals completely normalized the learning process [19]. It was then found that ACTH accelerates learning processes in intact animals [20], and that its action is independent of ACTH hormonal activity and likely results from a direct action on the CNS [21].

Numerous studies showed that the $\mathrm{N}$-terminal region of the ACTH molecule is the principal region responsible for the behavioral activity of the hormone and that the $\mathrm{ACTH}_{4-10}$ peptide is the minimal fragment retaining the behavioral effect of the full-length ACTH molecule, with complete loss of its hormonal activity [22-24]. It was shown in these cases that the Phe residue located at position 7 played the key role in the manifestation of the behavioral effects of ACTH fragments [25].

The study of the nootropic effects of different ACTH fragments showed that $\mathrm{ACTH}_{1-10}$ and $\mathrm{ACTH}_{4-10}$ influenced the learning of hypophysis-ectomized animals as successfully as $\mathrm{ACTH}_{1-24}$ did [26], and the positive action of $\mathrm{ACTH}_{4-10}$ on conditioned-response formation in intact animals was subsequently shown. The $\mathrm{ACTH}_{4-7}$ and $\mathrm{ACTH}_{5-10}$ fragments also accelerated the formation of conditioned responses, with $\mathrm{ACTH}_{4-7}$ being the most active of all the peptides studied $[27,28]$.

Clinical trials performed on volunteers proved that ACTH exerted a positive action on human cognitive abilities and improved attention and the ability to perform prolonged and monotonous work [29,30].

No uniform opinion regarding the mechanisms of ACTH action has been formed to date, and it is presumed that the influence of ACTH-family peptides on learning processes is caused by increased circulation of monoamine in the brain. It has been shown repeatedly that increased circulation and content of catecholamines and serotonin in different brain regions occurs after administration of ACTH and its fragments. A nootropic effect is also likely to occur because of the increased metabolism of acetylcholine in the hippocampus and cerebral cortex
[31].

In parallel with the nootropic effect of ACTH and its fragments, neuroprotective and neurotrophic effects were also shown. Studies performed on cultured neurons proved that ACTH exerted a trophic action in these cells and that even small doses $(10 \mathrm{nmol})$ of the hormone stimulated the growth of nerve fibrils [32]. The presence of ACTH fragments in the culture of serotoninergic neurons elicited the maturation of these cells and resulted in a larger amount of nerve cell projections [33]. Introduction of $\mathrm{ACTH}_{4-10}$ and $\mathrm{ACTH}_{1-24}$ into a culture of rat embryo brain cells yielded a larger density of neuronal nets and neuron links [34]. It was also demonstrated that peripheral nerve regeneration induced by $\mathrm{ACTH}$ and its $\mathrm{ACTH}_{4-10}$ fragment was accompanied by considerable enhancement of the synthesis of RNA and proteins in neurons. The fact that ACTH strengthened the synthesis of RNA and proteins and glucose utilization in the brain of old animals was also mentioned [35-37].

Regardless of the large body of experimental evidence testifying to the extrahormonal activity of ACTH and its fragments, it remains unclear to date which of the recaptors is involved in its nootropic, neuroprotective, and neurotrophic actions, with the melanocortin receptors MC3 and MC4 being the most probable candidates, as they are expressed in the brain $[38,39]$.

The discovery of the marked nootropic, neuroprotective, and neurotrophic effects of ACTH and its fragments rendered this peptide family one of the most promising candidates for the prevention and treatment of pathologies of the central nervous system. However, the application of these peptides in clinical practice appears to be difficult because of, first and foremost, the extreme instability and short-term effects of these peptides. Therefore, numerous synthetic analogs, ORG 2766 [40-44], HOE $427[45,46]$, ORG $31433[47,48]$, and BIM-22015 [49], which are more resistant to the action of proteases and many times more active, were created by replacing the natural left-handed amino acids in the ACTH molecule with right-handed amino acid residues. Nevertheless, the presence of nonnatural amino acids and radicals in the structure of these ACTH analogs yielded some new and at times negative biologic features; thus, no medical preparations based on the ACTH analogs described above have been produced.

In the late 1970s, a research team headed by Drs N.F. Myasoedov and I.P. Ashmarin initiated studies to create a nootropic peptide preparation based on ACTH and its fragments. As stated earlier, the shortness of the effect of natural ACTH fragments was a limitation to their application, as the duration of action of the most effective natural fragment, $\mathrm{ACTH}_{4-10}$, was as short as $30-60 \mathrm{~min}$, and an increase in the dose of the preparation administered yielded no effect $[10,11]$. The study of the noot- 
ropic activity of some $\mathrm{ACTH}_{4-10}$ analogs with various $\mathrm{C}$-terminal region modifications showed that the analog carrying a replacement of the three C-terminal amino acids with the Pro-Gly-Pro sequence displayed the longest activity. This peptide (H-Met-Glu-His-Phe-Pro-GlyPro-OH), termed Semax, exhibited the nootropic effect of its natural prototype, but its effect lasted for $20-24 \mathrm{~h}$. The study of the hormonal action of the peptide revealed that it had neither corticotropic nor melanocyte-stimulating activities [50].

The medical preparation "Semax 0.1\%" was produced in the form of nasal drops, and successfully passed all preclinical and clinical trials. It was introduced in clinical practice as a neuroprotective and nootropic remedy. By 2001, a new form of the preparation, the "Semax 1\%" nasal drops, that was intended for therapy following brain stroke was developed, and the range of the curative and preventive effects of "Semax 1\%" proved to be broad, including effects on conditions such as brain stroke, dyscirculatory encephalopathy, Parkinson's disease, ocular nerve atrophy, and a number of chronic pathologies caused by blood circulation deficiency in the brain. Moreover, the high efficacy of "Semax $0.1 \%$ " in preventive enhancement of intellectual capacity in healthy persons in extreme stress conditions has been reported. Finally, a pharmaceutical composition termed "Minisem" was specifically developed for newborn children (starting from the age of three) with neurological defects.

Although a medical preparation based on Semax is successfully used for prevention of and therapy for CNS diseases, further studies on the range of its physiological effects and mechanisms of action in the body are presently in progress.

\subsection{Basic Biologic Properties of Semax}

\subsubsection{Neuroprotective Effect}

Studies of the biologic effects of Semax in the body showed that this peptide has pronounced neuroprotective properties. It was found that Semax significantly reduced the number of damaged cells under conditions of oxidative stress caused by short-term incubation with hydrogen peroxide [51]. In addition, it significantly increased the survival of cerebellar granule neurons during glutamate neurotoxicity, which may be mediated by its effect on calcium homeostasis and on the functional state of mitochondria [52].

Experiments performed on cultures of embryonic rat brain cells showed that Semax at a dose of $0.1-10 \mu \mathrm{M}$ increased the number of surviving neurons by $1.5-3.0$ times compared with the control, without affecting the proliferation of glial cells [53]. Subsequent studies revealed that Semax at $100 \mathrm{nM}$ increased the survival of cholinergic neurons in the basal forebrain in vitro by 1.5 - 1.7 times and stimulated the activity of acetylcholinetransferase [54].

Studies of the antihypoxic properties of Semax performed on rats showed that this peptide increased the life span of the animal 2.5-fold at an extreme altitude (12,000 $\mathrm{m})$ and conferred adaptation to hypoxia. In studies performed using volunteers, Kaplan et al. showed that Semax arrested the posthyperventilation effects of EEG induced by a compensatory decrease in cerebral blood flow [55].

Studies of the effect of Semax after acute hypobaric hypoxia in rats of different ages showed that a single Semax pretreatment $(50 \mu \mathrm{g} / \mathrm{kg})$ led to an increase in individual resistance of animals to hypoxia, had a positive effect on the parameters of cardiac function during hypoxia, and reduced the behavioral changes, which are caused by oxygen deficiency [56]. A single intraperitoneal injection of Semax $(100 \mu \mathrm{g} / \mathrm{kg})$ significantly increased the time to breathing arrest in animals under hypoxia conditions. In addition, intranasal administration of the peptide for 6 - 7 days at a dose of $100 \mu \mathrm{g} / \mathrm{kg}$ increased the time to loss of posture and time to breathing arrest [10,57].

Studies have shown that intraperitoneal injection of Semax $(100 \mu \mathrm{g} / \mathrm{kg})$ significantly increased the overall resistance of rats to circulatory hypoxia and the survival of animals, and reduced the severity of the neurological defect. Yasnetsov showed that prior curative administration of Semax significantly reduced neurological damage in rats with cerebral ischemia caused by gravitational overload. In this case, there was a reduction in the effect of Semax with at high doses (in the range of $300-1200$ $\mu \mathrm{g} / \mathrm{kg}$ per day) [58].

The effect of Semax in global cerebral ischemia in rats with reduced levels of cerebral blood flow was studied. It was shown that the introduction of the peptide had a positive effect on the dynamics of cerebral blood flow and survival only in animals with a decompensated severe hemodynamic disorder of the brain [59]. It was established that double Semax intraperitoneal injection $(300 \mu \mathrm{g} / \mathrm{kg})$ exerted a neuroprotective effect and almost completely prevented the appearance of signs of neurological deficit and the increase in NO generation in the brain caused by ischemia $[60,61]$.

The neuroprotective and antiamnestic effects of Semax have been demonstrated in experimental ischemic infarction in prefrontal cortical areas. Systemic Semax administration $(250 \mu \mathrm{g} / \mathrm{kg})$ after local ischemic infarction significantly improved the rates of conditioned passive avoidance reflex [62]. Further studies showed that in rats with ischemic damage in prefrontal cortical areas, chronic administration of Semax $(250 \mu \mathrm{g} / \mathrm{kg})$ for 6 days after injury contributed to the restoration of spatial mem- 
ory and spatial learning ability [63].

The possibility of using Semax to correct postresuscitation neurological disorders was studied using a rat model of clinical death. Ligation of the vascular bundle of the heart was carried out to stop the general bloodstream. Animals were revived using a closed cardiac massage and artificial ventilation $10 \mathrm{~min}$ after clinical death, followed by the assessment of the degree of memory of the experimental environment via testing in the "open field". Daily intranasal Semax administration (50 $\mu \mathrm{g} / \mathrm{kg}$ ) for 2 weeks normalized the parameters of orienting-exploratory reaction in rats, bringing their values to the levels of those of the control $[64,65]$. Clinical studies of the effect of Semax on the restoration of amnestic brain function in patients with severe postresuscitational pathology (intellectual and mental disorders) showed that the majority of patients treated with Semax exhibited a significant improvement. A neuropsychological study revealed an improvement in attention, memory, cognition, mobility, muscle function, and audioverbal memory after Semax treatment. Electroencephalography confirmed the efficacy of Semax, as an improvement in the functional state of the brain was noted [66].

To identify a possible mechanism underlying the neuroprotective action of Semax, attempts were made at identifying the receptor of Semax using preparations of plasma membranes of neurons and glial cells and whole-brain neurons from rats. It was shown that Semax bound to the nuclear membranes of nerve cells of the basal forebrain of rats, which was specific and reversible [67].

The results of the study performed by Vyunova et al. showed the presence of the same type of specific binding sites on the membranes of the rat hippocampus and cerebellum; the highest number of binding sites was detected in the hippocampus. Specific binding to the membranes of the basal ganglia and cerebral cortex was found. Moreover, specific binding of Semax prevented any premature hydrolysis, which apparently confirmed the longterm pharmacological effect of the peptide [68].

\subsubsection{Neurotrophic Effect}

It has been suggested that the neuroprotective effects of Semax are associated with its effect on the expression of neurotrophins [53]. An experiment performed using a culture of glial cells resulted in rapid (within 30 min after Semax injection at $100 \mu \mathrm{g} / \mathrm{kg}$ ) induction of the transcripttion of the neurotrophin Bdnf and Ngf genes [69]. Furthermore, in vivo experiments have shown that in the hippocampus of healthy rats, Semax increased the expression of neurotrophin genes at the protein ( $B d n f$ and $\operatorname{TrkB}$ ) and mRNA (Bdnf, $\operatorname{TrkB}$, and $N g f$ ) levels [70-72].

Additional studies showed that a single Semax intranasal administration $(50 \mu \mathrm{g} / \mathrm{kg})$ led to an increase in $B d n f$ gene expression at the protein level in the rat hippocampus (by 1.4 times), which was accompanied by increased levels of tyrosine phosphorylation of TrkB (by 1.6 times) [71].

Studies of the functional morphology and proliferative activity of the brain cells of rats have shown that Semax and its C-terminal fragment Pro-Gly-Pro activate the capillary network and increase the proliferation of glia, the endothelium of blood vessels, and progenitor cells in the subventricular zone in healthy animals. A significant increase in the expression of the nuclear protein PCNA, which participates in the preparation for cell division, was also noted. Judging by the upregulation of PCNA in the nuclei of the brain cells of control animals, Semax appears to stimulate the proliferation of repopulating elements of the nervous tissue [73].

\subsubsection{Nootropic Effect}

Studies of the effect of Semax on animal learning showed that the intraperitoneal administration of the peptide at doses of $15-150 \mu \mathrm{g} / \mathrm{kg} 5 \mathrm{~min}$ before and after the training session accelerated the acquisition of a foodgetting habit in a T-maze. At similar doses of 15, 50, and $100 \mu \mathrm{g} / \mathrm{kg}$ administered $5 \mathrm{~min}$ before the training session, Semax significantly accelerated the training of animals in this test. The reduction of the dose to $5 \mu \mathrm{g} / \mathrm{kg}$ resulted in the disappearance of the effect. Introduction of Semax at a dose of $500 \mu \mathrm{g} / \mathrm{kg}$ did not influence learning by rats in the test used. Consequently, the increase in Semax dose does not lead to the reversal of its effects [10].

A positive effect of Semax on learning in animals regarding the conditioned passive avoidance reflex has been demonstrated. The introduction of the peptide (15 $\mu \mathrm{g} / \mathrm{kg}$ ) both 1 and $6 \mathrm{~h}$ before a training session improved learning by animals in this test. Consequently, the impact of Semax on the conditioned passive avoidance reflex does not depend on the sign of the reinforcing stimulus [10]. Semax also stimulated the amnestic processes not only in intact animals, but also in terms of pathology. Injection of the peptide before electroshock to test the conservation of passive avoidance in animals that suffered an electric shock led to a partial restoration of skills and attenuated amnesia caused by electroshock [11].

The study of the nootropic activity of Semax using various manners of drug administration in rats showed that the greatest nootropic effect of the peptide on the conditioned passive avoidance reflex was observed after intranasal administration of the peptide, whereas intraperitoneal injection yielded less pronounced effects [74]. Concomitantly, the effects of Semax after a single intranasal administration appeared after $4 \mathrm{~min}$ and lasted for $24 \mathrm{~h}$, which is 50 times greater than the length of action of the $\mathrm{ACTH}_{4-10}$ peptide [75,76]. In newborn rats, Semax contributed to increased selective attention and research 
activity and reduced the level of anxiety [77,78].

The work of Kaplan et al. using human volunteers showed that intranasal administration of the peptide (16 $\mu \mathrm{g} / \mathrm{kg}$ ) significantly increased the attention and shortterm memory of the subjects during testing, both at the beginning and at the end of the day. The introduction of the peptide at a dose of $250-1000 \mu \mathrm{g} / \mathrm{kg}$ caused changes in electroencephalographic parameters that were similar to the changes that arise after the administration of typical neuroprotective drugs [79].

Thus, these data seem to suggest that Semax can be administered to healthy individuals to prevent the negative impact of the environment, in particular the impact of long-term psychoemotional stress (increased information load, the effect of intense muscular workload, professional work in difficult conditions, a high degree of responsibility, conflict, financial problems, etc.).

\subsubsection{Anxiolytic Action}

The $c$-fos gene is overexpressed in different brain structures during emotional stress. The most pronounced expression of this gene was detected in the brain of animals that were susceptible to emotional stress. Preliminary intraperitoneal Semax administration caused a decrease in stress-induced $c$-fos gene expression in the paraventricular hypothalamus of rats predisposed to emotional stress [80].

Prior administration of the delta-sleep-inducing peptide and Semax to rats in the normal state increased $c$-fos gene expression, whereas the same oligopeptides inhibited emotional-stress-induced early $c$-fos gene expression. The change in the stress-induced expression pattern of the $c$-fos gene after administration of the delta-sleepinducing peptide and Semax may be due to the fact that the reception of these substances changes in these brain structures under emotional stress [81].

A study has shown that chronic intranasal Semax administration in white rats $(50 \mu \mathrm{g} / \mathrm{kg})$ for 10 - 14 days induced an anxiolytic and antidepressant activity, but had no effect on exploratory activity in nonstress conditions. The authors of that work attribute this effect of Semax to its ability to activate the serotoninergic system of the brain [82].

The effect of a single intranasal administration of Se$\max$ (at doses of 50 and $500 \mu \mathrm{g} / \mathrm{kg}$ ) on the levels of anxiety and depression in white rats has been studied. Semax had no effect on anxiety and depression in normal animals. However, when the levels of anxiety and depresssion were increased by the administration of the cholecystokinin-tetrapeptide, Semax had anxiolytic and antidepressant effects. The absence of anxiogenic activity could be due to the lack of the Phe-Arg-Trp-Gly sequence in its structure, which is available in the natural $\mathrm{ACTH}_{4-10}$ prototype and determines the anxiogenic prop- erties of natural melanocortins [83].

A positive modulator effect of Semax on the serotoninergic system of the striatum was also shown [84], with reduction of nociception [85] and normalization of the circadian locomotor rhythms [86].

A single intraperitoneal Semax injection at doses of 150 and $600 \mu \mathrm{g} / \mathrm{kg}$ increased the levels of dopamine, serotonin, and its metabolite 5-hydroxyindoleacetic acid. This effect was observed within $24 \mathrm{~h}$ after the administration of the peptide. Chronic daily administration of Semax (600 $\mu \mathrm{g} / \mathrm{kg}$ per day) for 7 days tended to reduce the levels of dopamine and serotonin significantly in the hypothalamus. These findings suggest the accelerated turnover of serotonin, reflecting an increase in the functional activity of this mediatory system [87]. Pretreatment with Semax potentiated the effects of D-amphetamine on the dopaminergic system of the striatum and on the locomotor activity of rats. The authors of that work suggest that Semax increases dopamine transmission in the striatum [88].

\subsection{Pharmacokinetics}

A comparative study of the stability of the Semax peptide and that of the native $\mathrm{ACTH}_{4-10}$ to the action of proteases in human blood serum showed that the primary degradation step in both cases is the cleavage of the N-terminal methionine by aminopeptidase. However, the natural fragment is rapidly degraded to individual amino acids, whereas Semax forms rather stable intermediates with the structure Glu-His-Phe-Pro-Gly-Pro, which exhibit neurotrophic activity in the same range as that of Semax $[75,76]$. Subsequently, this fragment undergoes sequential degradation under the action of dipeptidyl aminopeptidase, which cleaves it to His-Phe-Pro-Gly-Pro and ProGly-Pro. Determination of the levels of Pro-Gly-Pro in the serum within $3-5 \mathrm{~h}$ of the introduction of Semax using different approaches (intraperitoneal, intragastric, and intracolonic) revealed that its content does not exceed $2 \%-5 \%$ of the total amount of injected peptide. The Pro-Gly-Pro peptide is hydrolyzed by enzymes of the serum, forming fragments of Pro-Gly and Gly-Pro, and influences the number of processes in the body. Subsequently, aminopeptidase and the angiotensin-converting enzyme degrade these fragments to amino acids [89]. The half-life of Semax in the serum is $>1 \mathrm{~h}$. Its prolonged effect is associated with the cytoprotective activity of its fragments [90].

The study of Semax degradation in the presence of plasma membranes of nerve cells, as well as in cultures of glial and nerve cells derived from rat forebrain, showed that Semax degradation retains the $\mathrm{N}$ - and $\mathrm{C}$ termini in all cases. However, the cleavage of the peptide containing the $\mathrm{N}$ terminus is more intense. The main 
route of degradation is the cleavage of the $\mathrm{C}$ - and Nterminal dipeptides, to form the pentapeptides His-PhePro-Gly-Pro and Met-Glu-His-Phe-Pro [91]. Thus, as a result of fairly rapid enzymatic degradation, Semax in brain tissues is a mixture of peptide derivatives with different compositions [92].

A comparative study of the nootropic activity of the products of the enzymatic degradation of $\mathrm{ACTH}_{4-10}$ and Semax (Glu-His-Phe-Pro-Gly-Pro, His-Phe-Pro-Gly-Pro, and Phe-Pro-Gly-Pro) showed that $\mathrm{ACTH}_{4-5}$ and GluHis-Phe-Pro-Gly-Pro have neurotropic activity [93].

The results of that study led to the conclusion that the products of the enzymatic degradation of $\mathrm{ACTH}_{4-10}$ and Semax have their own neurotrophic activity and are synergistic regarding their effect on learning processes. Consequently, the observed effects of these peptides may be the result of the global action of the original heptapeptide and its derivatives. The high activity and relative stability of the hexapeptide Glu-His-Phe-Pro-Gly-Pro greatly ensures the long-term effect of Semax [11].

After intravenous administration, about $0.01 \%$ of Semax penetrates the blood-brain barrier [76,94], whereas $0.093 \%$ of Semax penetrates this barrier 2 min after intranasal administration [92]. Semax has a half-life in the body of a few minutes, and its therapeutic effect persists for $20-24 \mathrm{~h}$ after the administration of a single dose [76]. Consequently, intranasal Semax administration is as effective as intraperitoneal injection. This is the basis for the recommendation of the intranasal route for Semax administration in humans.

\subsection{Effect of Semax on Gene Transcription}

One important aspect in the study of the mechanism of action of natural regulatory peptides and their synthetic analogs is their ability to influence gene expression at both the mRNA and protein levels. The ability of Semax to increase the survival of rat brain neurons and the existence of Semax-binding sites on brain plasma membranes indicate that the physiological effects of the peptide can be exerted through the influence of the state or function of brain cells. Grivennikov et al. [53] suggested that the neuroprotective effects of Semax are associated with its effect on the expression of a family of regulatory proteins, the nervous-tissue neurotrophins, which are synthesized by neurons and glial cells and promote the differentiation and the maintenance of the viability and function of peripheral and central neurons.

Shadrina et al. [69] first showed that Semax caused a rapid (within $30 \mathrm{~min}$ ) induction of the transcription of the neurotrophin $B d n f$ and $N g f$ genes in glial cell cultures. The Bdnf mRNA levels increased 8-fold and the $N g f$ mRNA levels increased 5-fold. The results of subsequent in vivo experiments demonstrated that Semax upregulates neurotrophin genes $(B d n f, \operatorname{Trk} B$, and $N g f)$ at the mRNA level in the hippocampus of healthy rats [70]. Further studies showed that a single intranasal administration of Semax $(50 \mu \mathrm{g} / \mathrm{kg})$ led to upregulation of the $B d n f$ and $\operatorname{TrkB}$ mRNAs in the rat hippocampus by 3 - and 2-fold, respectively [71].

Agapova et al. [72] assessed the effect of the administration of a single intranasal dose of Semax $(50 \mu \mathrm{g} / \mathrm{kg})$ on the maintenance of $B d n f$ and $N g f$ mRNA levels in different parts of the rat brain and retina. One hour after Semax administration, a significant increase in $B d n f$ gene expression was observed in the hippocampus, cerebellum, and brain stem. The levels of $N g f$ mRNA were significantly increased in the hippocampus and decreased in the frontal cortex.

Evaluation of the temporal dynamics of the changes in neurotrophin mRNA levels showed that the intranasal administration of a single dose of Semax $(50 \mu \mathrm{g} / \mathrm{kg})$ yielded a rapid response of the $B d n f$ and $N g f$ genes in the rat hippocampus and frontal cortex, as demonstrated by a significant change in their expression within 20 min after Semax administration. A decrease in $B d n f$ and $N g f$ mRNA levels was observed in the hippocampus. In contrast, an increase in the mRNA levels of these genes was observed in the frontal cortex. A similar temporal dynamics of the changes in the expression of these two genes was observed within the same brain structures. In addition, two peaks of expression were noted for both genes: the first peak was observed $1.5 \mathrm{~h}$ after administration of Semax (Bdnf, 1.38 and 1.32 times in the hippocampus and frontal cortex, respectively; Ngf, 1.38 and 1.11 times, respectively) and the second peak was observed $8 \mathrm{~h}$ after administration of Semax (Bdnf, 1.75 and 1.64 times in the hippocampus and frontal cortex, respectively; $N g f, 1.67$ and 1.65 times, respectively) [95].

Later, it was shown that the intranasal administration of a single dose of Semax at a similar concentration elicited both fast and long-term changes in Bdnf and $N g f$ gene expression in the rat hippocampus, frontal cortex, and the retina. It was noted that the temporal dynamics of the changes in the expression of these genes under the influence of Semax in all tissues examined was similar. The greatest increase in the mRNA levels of both genes was observed in the hippocampus, frontal cortex, and retina $8 \mathrm{~h}$ after the administration of the peptide [96].

Agapova et al. studied the effect of Semax on the expression of genes involved in intracellular signaling pathways in the hippocampus of healthy animals using the "RT"Profiler" PCR Array Signal Transduction Pathway Finder" panel (SABioscience, USA), which includes 84 genes. Those authors found that the intranasal administration of a single dose of the peptide (50 $\mu \mathrm{g} / \mathrm{kg}$ ) led to a change in the mRNA levels of several genes involved in the implementation of the Wnt (Ccnd1, 
Cdh1, Pparg, and Vegf) and NF-kB (Birc2, Tnfb, Ifl, Nos2a/iNos, and Tnfa) pathways, which are involved in the regulation of processes associated with the survival of neurons and neuronal cell cultures [97].

To elucidate the molecular mechanism underlying the neuroprotective actions of Semax in pathological conditions, the effect of Semax and its most stable metabolite (Pro-Gly-Pro) on the mRNA content of genes encoding growth factors and their receptors was investigated in focal cerebral ischemia. For this purpose, the "RT2Profiler ${ }^{\mathrm{TM}}$ PCR Array Rat Neurotrophin and Receptors" panel (SABioscience, USA) was used. Among the 84 genes studied, the expression of 19 genes was significantly altered. During ischemia, Semax and its Pro-GlyPro metabolite had an impact on the expression of mRNA growth factors and their receptors, increasing the expression of some and reducing that of others. The spectrum of genes that exhibited a change in expression levels under the influence of both peptides overlaps only partially. The most pronounced changes (by 2 or more times) in expression under the influence of Semax and Pro-Gly-Pro were observed for Lif, Galr, TrkA, and $p 75$. Thus, these studies have shown that the mechanisms of action of Semax and Pro-Gly-Pro on the nervous tissue exhibit specific features. The authors suggested the existence of two types of growth-factor targets: neural tissues (neurons and glial cells) and cells of the vascular wall [98].

Subsequently, those authors investigated the effect of Semax and Pro-Gly-Pro on the transcription of neurotrophins and their receptors in the cortex of rats with focal cerebral ischemia. Semax increased the transcription of Bdnf, TrkC, and TrkA at $3 \mathrm{~h}, N t-3$ and $N g f$ at $24 \mathrm{~h}$, and $N g f$ at $72 \mathrm{~h}$ after occlusion. Pro-Gly-Pro, in turn, increased the transcription of $B d n f$ and $\operatorname{TrkC}$ at $3 \mathrm{~h}$ and $N g f$, $\operatorname{TrkB}, \operatorname{Trk} C$, and $\operatorname{Trk} A$ at $24 \mathrm{~h}$ after occlusion. Hence, it was suggested that the activation of the expression of the neurotrophin system under Semax and Pro-Gly-Pro action may contribute to the neuroprotection and survival of neural cells after ischemia. It should be noted that this activating effect was mainly observed $3 \mathrm{~h}$ and $24 \mathrm{~h}$ after the ischemic attack, a time at which some cells in the peripheral ischemic focus retain functional activity and are able to survive. In addition, Semax administration led to changes in the expression of neurotrophins and their receptors mainly in the ischemic cortex, whereas the effect of Pro-Gly-Pro was less specific. This may indicate that these peptides have specific mechanisms of action that differ from each other [99].

Stavchansky et al. studied the effect of the synthetic peptide Semax and its C-terminal fragment Pro-Gly-Pro on the expression of neurotrophin genes ( $N g f, B d n f$, and $N t-3)$ and their receptors $(\operatorname{Trk} A, \operatorname{Trk} B, \operatorname{Trk} C$, and $p 75)$ in the frontal lobes, hippocampus, and cerebellum of a rat model of incomplete global cerebral ischemia. A change in the expression of many genes (in particular those encoding neurotrophin receptors) has been observed in the frontal cortex of ischemic animals. The most noticeable ischemic effect acted on the expression of neurotrophins and their receptors in the hippocampus. A reduction in the relative content of the mRNA levels of $N t-3, \operatorname{TrkB}$, $\operatorname{Trk} C, p 75$, and $\operatorname{Trk} A$ genes was observed within the first few hours after occlusion, and a significant decrease in the expression of most genes studied was observed $8 \mathrm{~h}$ and $12 \mathrm{~h}$ after occlusion.

Thus, the administration of Semax and Pro-Gly-Pro has a significant effect on the expression of neurotrophin genes and their receptors predominantly in the frontal cortex and hippocampus of ischemic animals. In the frontal cortex of rats under the influence of Semax, the mRNA levels of neurotrophin receptor genes were downregulated, whereas they were upregulated under the influence of Pro-Gly-Pro. The maximal neuroprotective effect of peptides was observed in the hippocampus of animals $12 \mathrm{~h}$ after occlusion, a time at which the ischemic injury resulted in a significant decrease in the expression of neurotrophin genes and their receptors. Thus, the use of Semax and Pro-Gly-Pro at this time offsets ischemia-mediated changes in gene expression [100].

\subsection{Clinical Application}

\subsubsection{Neurology}

1) Vascular Brain Diseases

Vascular diseases of the brain are a major cause of death worldwide with ischemic brain lesions being predominant (80\%) among the cerebrovascular diseases. In recent years, a clear temporal sequence of molecular and biochemical mechanisms that trigger acute focal cerebral ischemia has been established. The close relationship among the long-term effects of ischemia as well as their common trigger mechanisms allow for secondary neuroprotection in addition to local action via the use of the modulating effect of regulators, including the major role played by neuropeptides [101-105]. Given that neuropeptides can easily penetrate the blood-brain barrier (in contrast with the polypeptide chains of growth factors); it is difficult to overestimate their potential therapeutic significance.

Experiments using tissue cultures and animal models of cerebral ischemia, as well as clinical conditions, established the neuroprotective effect of the drug "Semax 1\%", the main effects of which are the inhibition of glial inflammatory responses, improvement of the trophic support of the brain, inhibition of nitric oxide synthesis, and other reactions of oxidative stress and immunomodulation. The steps in the Semax-induced chain of metabolic transformations reinforce and support each other, leading 
to inhibition of the most important mechanisms of delayed cell death [106].

The evaluation of the effectiveness of "Semax 1\%" in the treatment of patients with various cerebrovascular diseases showed that after treatment, most patients exhibited a significant improvement in overall health (reduced headaches, normal sleep, increased efficiency, increased level of memory and concentration, reduced anxiety) [107].

Clinical studies showed a positive effect of Semax in acute hemispheric ischemic stroke. Intranasal Semax administration as an intensive therapy for acute hemispheric ischemic stroke had a beneficial effect on the quality and pace of the recovery processes, as it helped to accelerate the regression of brain and focal abnormalities [108].

The role of immune responses and local inflammation in the pathogenesis of ischemic stroke and in the formation of infarction changes in brain tissues is well documented. Their importance in the development of an inflammatory response not only to the excessive release of proinflammatory cytokines (IL-1 $\beta$, TNF- $\alpha$, and IL-8), but also to the lack of protective anti-inflammatory and trophotropic factors (IL-10 and TGF- $\beta$ ) has been established $[106,108,109]$. The investigation of the immunobiochemical mechanisms underlying the neuroprotective action of Semax in acute ischemic stroke showed that the introduction of the peptide leads to a change in the balance of peptidergic systems of the brain toward the predominance of anti-inflammatory and trophic protective factors (IL- 10 , TNF- $\alpha$, and TRF- $\beta$ ) over proinflammatory factors (IL-8 and C-reactive protein) [110].

Thus, those authors showed that the drug "Semax 1\%" is well tolerated and has no toxicity or significant side effects (indicated by a discoloration of the mucous membrane of the nasal cavity in $10 \%$ of patients and a mild increase in the concentration of glucose in the blood of $7.4 \%$ of patients with diabetes). Therefore, Semax has a strong neuroprotective effect. The Semax-induced chain of metabolic reactions plays a role in all of the major mechanisms underlying the long-term effects of ischemia, underscoring the promise of its application as a neuroprotector in patients with ischemic stroke.

2) Dyscirculatory Encephalopathy

Dyscirculatory encephalopathy is the progressive chronic cerebrovascular insufficiency that leads to the development of multiple small focal necroses of brain tissue and manifests itself as gradually increasing defects in brain function [111,112].

A clinical trial of the action of Semax in patients at different stages of dyscirculatory encephalopathy showed that Semax treatment (9 and $12 \mathrm{mg}$ per day) led to significant clinical improvement, helped stabilize the progression of the disease, and reduced the risk of stroke and transient ischemic attacks in the course of the disease. The drug elicited a small percentage of side effects, which were well tolerated by patients (including older patients) [113].

\subsubsection{Ophthalmology}

1) Optic Nerve Atrophy

Clinical studies of the efficacy of "Semax $0.1 \%$ " as a therapy for brain diseases were a prerequisite for clinical efficacy studies on optic nerve disease, which is one of the worst pathologies of the visual analyzer and often leads to partial or complete atrophy of the optic nerve and, consequently, impaired vision or blindness [114].

Studies have shown that the inclusion of "Semax $0.1 \%$ " in complex therapy for optic nerve diseases has a beneficial effect on the quality and pace of the recovery processes and helps improve visual function. The result is the directly stimulating effect of an electric current on the activation of blood circulation, which increases cell metabolism activity [115].

The use of "Semax $0.1 \%$ ", particularly in the acute stage of diseases of the optic nerve, effectively protects nervous tissues from the effects of damage by significantly increasing the positive clinical dynamics of the estimated increase in visual acuity, expanding the total field of view, increasing the electrical conductivity and the sensitivity of the optic nerve, and improving color vision [116].

2) Glaucoma Optic Neuropathy

According to modern concepts, the pathogenesis of glaucoma optic neuropathy, which is characterized by loss of retinal ganglion cells, has much in common with that of chronic cerebral ischemia $[102,117,118]$. The considerable successes in the treatment of ischemic neurological diseases, as well as of some forms of optic atrophy, with "Semax $0.1 \%$ " suggest its potential therapeutic effect in the treatment of glaucoma optic neuropathy $[110,116]$.

Research on the effectiveness of "Semax $0.1 \%$ " in the treatment of primary open-angle glaucoma at the developed and advanced stages in patients with normalized ophthalmotonus showed that 1 month after initiation of treatment, a number of functional indicators that reflect the status of the optic nerve (relative and absolute number of defects in the central field of view and color sensitivity) were significantly improved compared with those of patients who received only basic therapy.

The best results of treatment on all indicators were achieved in patients with advanced glaucoma and advanced glaucoma compensated by surgery who received "Semax $0.1 \%$ " via electrophoresis for 10 days, followed by intranasal instillation within 10 days. These patients exhibited significantly improved visual acuity, and extension of the boundaries of the visual fields [115]. 


\section{3) Nonproliferative Diabetic Neuropathy}

We evaluated the efficacy of the drug "Semax $0.1 \%$ " in the treatment of patients with nonproliferative diabetic retinopathy, which develops in the presence of diabetes mellitus type II. All patients exhibited positive dynamics of the functional parameters (perimetric and electrophysiological) after the treatment [119].

\section{Selank Is a New-Generation Antianxiety and Noot-Ropic Compound}

\subsection{Background}

A common system of regulation exists among the major regulatory systems of the body. Based on this fact, it has been suggested that endogenous regulators of one system can affect the regulation of another [120].

Tuftsin was one of the first peptides of the immune system for which a distinct influence on the functions of the CNS was described. Tuftsin is a tetrapeptide with the sequence Thr-Lys-Pro-Arg. It was isolated in 1970 by Najjar and Nishioka from the leucophilic fraction of the IgG protein [121]. Tuftsin is a $289-292$ amino acid stretch of the $\mathrm{CH} 2$ domain of the Fc fragment of the leucokinin molecule $[122,123]$.

Tuftsin acquires its activity after excision from the protein carrier via the successive action of two enzymes: splenic tuftsin endocarboxypeptidase, which cuts the $\mathrm{C}$ terminus of tuftsin, and the phagocytic enzyme leucokinase, which cuts its $\mathrm{N}$ terminus [124-127].

Specific receptors for tuftsin are found exclusively in cells that have $\mathrm{Fc}$ receptors for IgG: monocytes/macrophages, neutrophils, and NK cells. After tuftsin-receptor interaction, the complex is internalized by macrophages [128]. In vivo, tuftsin is delivered to cells that possess specific receptors as part of the "antigen-antibody" complex [129].

The principal biologic activity of tuftsin consists of the activation of phagocytosis by granulocytes and macrophages. It also activates pinocytosis, increases the respiratory burst of phagocytic cells (thus stimulating their bactericidal activity), destroys neoplastic cells, and affects the formation of antibodies. Tuftsin stimulates the formation of superoxide and nitroxide radicals by macrophages, which leads to an increase in their digestive capacity $[124,130,131]$. In vivo experiments showed that tuftsin induces strong antibacterial activity without apparent toxicity. It increases the cytotoxic action of $\mathrm{T}$ lymphocytes and stimulates the synthesis of antibodies [132-134].

In the early 1980s, Valdman and Ashmarin hypothesized that the regulator of the peripheral immune system, tuftsin (which exhibited structural similarity to a family of neuropeptides), has an impact on the CNS $[9,135]$. Herman et al. found that the intraventricular administra- tion of tuftsin to rats elicited analgesia that lasted for 20 min, as assessed using the hot-plate test $[136,137]$. Among the various tuftsin analogs only the dipeptide Pro-Arg exhibited any evident analgesic action, as assessed using both the hot-plate and the tail-immersion tests $[138,139]$.

Intraperitoneal administration of tuftsin at a dose of $500 \mathrm{mg} / \mathrm{kg}$ yielded enhanced locomotor activity and aggressiveness and diminution of the acquisition of the passive avoidance reaction during a single reinforcement [135]. Semenova et al. found that IP injection $(300 \mathrm{mg} /$ $\mathrm{kg}$ ) of tuftsin to rats induced an increase in the stability of memory traces during a 30-day period and affected learning and exploratory behavior in rats [140,141].

Experiments performed using dogs, cats, rabbits, and rats showed that tuftsin modifies the configuration of the evoked potentials, especially in the visual cortex, as well as augmenting catecholaminergic and suppressing serotoninergic activity in the sensorimotor cortex and caudate nucleus [142,143]. Administration of a single dose of tuftsin distinctly altered the synthesis and degradation of monoamines, acetylcholine, and proteins in the cortexsubcortex structures of the brain locomotor system. Tuftsin normalizes the levels of dopamine, norepinephrine, and serotonin [144].

The relation between the brain monoaminergic systems and the effects of tuftsin on animal emotional behavior was also studied by Semenova et al. Those authors found that intracutaneous administration of tuftsin to rats neonatally treated with 5,7-dihydroxytryptamine resulted in a weakened perception of stress situations, an increase in the stability of investigative behavior, and a normalization of serotonin levels in the brain [145].

This wide biologic activity of tuftsin is of considerable interest in relation to the use of this peptide and its derivatives as drugs. However, natural peptides are highly unstable when injected into the body, and have a shortterm effect. Russian scientists conducted a detailed study of the synthesis and long-acting effect of tuftsin analogs. The result was a heptapeptide containing the sequence Thr-Lys-Pro-Arg elongated with the C-terminal part of the tripeptide Pro-Gly-Pro, which proved to be most suitable for the stabilization of the molecule and enhanced its resistance to proteases. The resulting peptide, H-Thr-Lys-Pro-Arg-Pro-Gly-Pro-OH, which was named Selank, had a pronounced anxiolytic activity. The drug "Selank $0.15 \%$ ", in the form of nasal drops, was developed based on this peptide and has successfully passed all preclinical and clinical trials. In 2009, the drug was registered by the Russian Federation Ministry of Health and approved for medical use. It has been successfully introduced into clinical practice as an anxiolytic and nootropic drug and has been widely recognized by specialists. However, despite the successful use of "Selank 
$0.15 \%$ " in the prevention and treatment of generalized anxiety disorder and neurasthenia, the study of the spectrum of its physiological effects and mechanisms of action is still ongoing.

\subsection{Basic Biologic Properties of Selank}

\subsubsection{Anxiolytic Effect}

In 1960, Sudakov hypothesized that the resistance of biologic objects to emotional stress should be determined by endogenous peptide substances [146]. Studies aimed at exploring the psychotropic and anxiolytic properties of peptide compounds revealed that the most active in this regard were drugs belonging to the tuftsin family [135, 147].

The study of the adaptive behavior of animals in stress situations under treatment with tuftsin and its derivatives showed that the most universally positive effect of this drug in all model situations included Selank and the pentapeptide Pro-Arg-Pro-Gly-Pro (intraperitoneal injection at a dose of $300 \mu \mathrm{g} / \mathrm{kg}$ ). Its peptides exhibited the most pronounced anxiolytic effect and significantly activated the exploratory activity of animals $[147,148]$.

Sollertinskaya et al. showed that Selank has pronounced neuropsychotropic, antidepressant, and antistress effects and abolishes the reaction of aggression and fear in primates with neurosis. The compensatory effects of Selank have a dose-dependent character. The dynamics of recovery of psychic functions in previously neurotized animals after use of the preparation at high doses (300 $\mu \mathrm{g} / \mathrm{kg}$ ) is longer than that observed after the use of low doses $(30-50 \mu \mathrm{g} / \mathrm{kg})$. The compensatory effects of Selank occur in both inhibitory and excitatory neurosis types. Compared with the neurohormones studied previously (thyroliberin, vasopressin, and $\mathrm{ACTH}_{4-10}$ ), Selank has a prolonged effect and no side effects and, on the whole, is unidirected in young and elderly monkeys [149].

Seredenin et al. studied the behavioral effects of Selank in BALB/c and C57BL/6 mice with different types of emotional stress reactions. It was shown that the administration of Selank at doses of $200-3000 \mu \mathrm{g} / \mathrm{kg}$ under avoidable and unavoidable stress had a significant anxiolytic effect on BALB/c mice with an initially high level of anxiety and had no significant effect on C57BL/6 mice with low levels of anxiety and an active type of emotional stress reaction. This effect of Selank is comparable to the effect of benzodiazepine tranquilizers at low doses; however, the action of Selank is not accompanied by undesirable characteristics (hypnosedation and myorelaxation) and side effects (amnesia, withdrawal, and dependence) $[150,151]$.

Narkevich et al. have shown that Selank administration to mice with different types of emotional stress reac- tions in the "open field" test causes significant variations in the levels of noradrenaline (NA), dopamine (DA), serotonin (5-HT), and their major metabolites in different brain regions. In particular, the content of 5-HT and its metabolite 5-hydroxyindoleacetic acid (5-HIAA) in the hippocampus of BALB/c mice with an initially high level of anxiety was higher than that of C57BL/6 animals with an active type of emotional stress reaction. Selank administration $(300 \mu \mathrm{g} / \mathrm{kg})$ caused an increase in NA content in the hypothalamus of both lines of mice and changes in concentrations of DA metabolites (3,4-dihydroxyphenylacetic and homovanillic acids) in the hippocampus and frontal cortex. C57BL/6 mice exhibited a significant increase in the value of these indicators, whereas BALB/c mice showed a decrease in these values. The administration of Selank caused a significant decrease in serotonin and 5-HIAA concentration in the hippocampus only of BALB/c mice. These results confirmed the selectivity of the Selank effects [152].

The anxiolytic action of Selank under Naloxone-induced disturbance of the brain opioid system has been studied. It was shown that intraperitoneal Selank administration $(250 \mu \mathrm{g} / \mathrm{kg})$ caused an increase in the general motor activity of BALB/c mice and had no effect on the behavior of C57BL/6 mice. Naloxone altered the phenoltype of the source of emotional and stress responses in BALB/c mice, causing a reaction of "rapid escape" in the "open field" peripheral zone, and eliciting the opposite effect in C57BL/6 mice, as reflected in the fading reaction. After Naloxone treatment, the sensitivity to the anxiolytic action of Selank decreased in BALB/c mice and increased in C57BL/6 mice. These results allowed the identification of a new target of Selank action in the CNS and suggested the importance of the activity of opioid systems in the formation of individual sensitivity to Selank [153].

The anxiolytic effect of Selank was studied in a new model of innate (genetically determined) behavioral symptoms of depression, the rat inbred line WAG/Rij. It was found that repeated Selank administration in large doses $(1000-2000 \mu \mathrm{g} / \mathrm{kg})$ eliminated the symptoms of depression in the behavior of rats, but had no effect on the level of general motor activity. Thus, these results demonstrated the presence of a specific component in the spectrum of Selank antidepressant activity [154].

The mechanism underlying the action of Selank remains unclear; however, it is assumed that it is based on the ability of the peptide to inhibit enkephalin-degrading enzymes and to prolong the half-life $(\tau 1 / 2)$ of opioids in the body [155]. It is known that opioid peptides are involved in the pathogenesis of anxiety and phobic states. Thus, animals with knockout of $\delta$-opioid receptors exhibit elevated levels of anxiety [156]. Behavioral experiments revealed the anxiolytic effects of an agonist of 
$\delta$-opioid receptors, dalargin [157].

Intraperitoneal administration of Selank at doses of 10, 100,1000 , and $10,000 \mu \mathrm{g} / \mathrm{kg}$ reduced the behavioral manifestations of apomorphine-induced dopaminergic system hyperactivity and completely blocked the effects of the nonselective opioid receptor antagonist Naloxone. However, the direct binding of the peptide to dopamine and opioid receptors has been reported. As enkephalinase inhibitors together with opioid receptor agonists and antagonists modulate the status of the dopaminergic system, the authors assumed that the effect of Selank is mediated by its ability to modulate the status of the endogenous opioid system via changes in the activity of enkephalindegrading enzymes [158].

A radioligand analysis indicated that the $\tau 1 / 2$ of enkephalin in the blood of mice varies according to the different types of emotional stress response. In intact $\mathrm{BALB} / \mathrm{c}$ mice with high levels of anxiety, this characteristic is much lower than that observed in stress-resistant C57BL/6 mice. This ratio was maintained in stressful conditions. This result confirms the selective anxiolytic effects of Selank in animals with an initially higher level of enkephalinase activity. Thus, Selank increases the functional activity of the endogenous opioid system, thereby prolonging the circulation time of enkephalins in the blood [159].

In addition, peptides generally labeled with tritium were used to show that Selank significantly decelerates the degradation of enkephalin by human blood plasma enzymes. Selank completely inhibits carboxypeptidases, decreases the activity of dipeptidylcarboxypeptidases almost 20-fold, and reduces the accumulation of the products of the N-terminal hydrolysis of Leu-enkephalin only 2 -fold. Consequently, Selank can be considered a relatively selective inhibitor of carboxy- and dipeptidylcarboxypeptidases of blood plasma, which cleave Leuenkephalin. In the presence of $15 \mu \mathrm{M}$ Selank, the biodegradation of Leu-enkephalin in blood plasma proceeds in a more selective manner compared with a condition without the drug, via a pathway associated with the action of aminopeptidases. These enzymes hydrolyze not only enkephalins, but also several other regulatory peptides. Thus, the mechanism underlying the biologic activity of Selank may be associated with its effect not only on the opioid system, but also on several other systems of regulatory peptides [160].

The effect of tuftsin and Selank on serotonin exchange in the rat brain after pretreatment for 4 days with the serotonin-synthesis inhibitor p-chlorophenylalanine (PCPA) was studied. Increased metabolism of serotonin was observed $30 \mathrm{~min}$ after Selank injection into the caudal section of the brainstem - the area of localization of the dorsal raphe nuclei, in which synthesis of serotonin occurs. In contrast, the metabolic rate remained unchanged in animals injected with PCPA after tuftsin administration [161].

\subsubsection{Nootropic Effect}

Tuftsin and its derivatives have an effect on learning and memory in rats. It has been established that Selank has a significant positive action on learning processes in rats via a conditioned passive avoidance reflex [162]. The investigation of the conditioned active avoidance reflex in rats with different phenotypes regarding emotional and stress reactions (active and passive) revealed that Selank $(300 \mu \mathrm{g} / \mathrm{kg})$ significantly enhances the learning process in both groups. The highest Selank efficiency was achieved on day 3 of training, at the stage of the outbreak and emerging memory consolidation, and progressively increased with further administration of the peptide. A significant increase in the number of correct responses was attributed to the antianxiolytic component of Selank. It is known that anxiety and fear hamper the process of conditioned reflex reactions to aversive effects. An activating effect of Selank was observed after its administration to rats with initially low levels of learning. Under these conditions, this activating effect was observed on the first day after the single injection of the peptide and increased progressively with repeated administration over the entire period of study $[163,164]$.

There is a relationship between stressors and diseases of the CNS, such as anxiety and depression [165]. In addition, the pathophysiological effects of stress are associated with exposure to the functions of the hippocampus, which may be regulated by the brain-derived neurotrophic factor (BDNF). BDNF is involved in learning and the formation of memory engrams in the mammalian brain and regulates synaptic function of shortterm and long-term synaptic potentiating by binding to specific TrkB receptors on postsynaptic neurons $[166$, 167]. The downregulation of endogenous BDNF in rat brain leads to disturbances in learning and memory formation [168]. The investigation of the effect of Selank on $B d n f$ gene expression in the hippocampus of rats showed that the peptide increases the levels of the $B d n f$ mRNA 3 $\mathrm{h}$ after its administration $(250$ and $500 \mu \mathrm{g} / \mathrm{kg}$ ) and the levels of the BDNF protein $24 \mathrm{~h}$ after its administration at both doses. Increased expression of BDNF suggests that Selank stimulates the expression of the neurotrophic factor in cells of the hippocampus, but not its axonal transport from remote areas of the brain [169].

The ability of Selank to adjust the parameters of integrative brain activity and the level of endogenous amines in adult rats subjected to antenatal hypoxia has been described. Hypoxia disrupts the balance of natural amines in brain structures, emotional behavior, and cognitive processes. These rats manifest significant alterations in cognitive function, emotional behavior, and the balance 
of activity in monoaminergic systems. These changes persist for at least 4 months after birth. Biochemical studies have shown that a single administration of Selank $(300 \mu \mathrm{g} / \mathrm{kg})$ leads to significant changes in the levels of noradrenaline, dopamine, serotonin, and their metabolites in the rat brain. The duration of these changes is comparable to the duration of the effect of Selank on the behavior of the animals. Thus, the action of Selank on the integrative brain activity of rats subjected to antenatal hypoxia is accomplished by restoring the normal balance of monoaminergic systems, which is accompanied by the compensation of behavioral disorders [170,171].

The positive effects of Selank on the cognitive processes resulting from a damaged catecholaminergic system of the brain in the early stages of ontogeny have been reported. Administration of Selank $(300 \mu \mathrm{g} / \mathrm{kg})$ in the early stages of learning facilitates the process and has a positive effect on the preservation of these skills. The administration of Selank to animals with reduced activity of the catecholaminergic system is accompanied by an improvement in the process of consolidating a memory track and expedites the formation of a conditioned passive avoidance reflex [172].

The investigation of the activity of Selank to remedy the alterations in the processes of learning and memory caused by damage of the noradrenalinergic system showed that the main component of the Selank effect is the stimulation of the search reflex aimed at a different adaptive response. Experiments performed using Wistar rats with destruction of the noradrenalinergic system of the brain caused by the disulfiram 6-hydroxydopamine and exposure to hypoxia with hypercapnia established the protective properties of Selank. It was shown that Selank compensates for the learning and memory damage that is associated with exposure to these neurotoxic factors. The acceleration of the consolidation and reproduction processes suggests that Selank stimulates the motivation brain mechanisms that are responsible for this damage [173].

The effect of Selank on the processes of learning and memory and on the level of serotonin (5-HT) was investigated in animals that received 30 training sessions in 1 day and were conditioned to food reinforcement. Selank $(300 \mu \mathrm{g} / \mathrm{kg}$ ) was administered after the tenth run; subsequently, the 30-min training sessions were continued. Preservation of the reaction was tested after 24 h, 7 days, and 30 days. It was established that a single dose of Selank causes a significant enhancement in serotonin metabolism in the hypothalamus and caudal brain stem and improves the stability of memory traces for 30 days. These data suggest that the administration of Selank during the consolidation phase improves the process involved in saving memory traces. The nootropic activity of Selank is due to its action at the level of serotonin and its metabolites in the brain [174].

Given the involvement of biogenic amines in the regulation of biorhythmological processes, the seasonal effect of Selank on the behavior of hibernating animals was investigated. Long-tailed ground squirrels were divided into three groups according to the different stages of the seasonal cycle: the final stage of sleep, the period of maximum activity, and preparation for hibernation. A single injection of Selank into the animals in the first group exerted an activating effect of orienting-exploratory behavior in the "open field" test. In the second group, no significant differences were identified between the test animals and the controls. The third group exhibited an increase in research activity after Selank injection. Locomotor activity did not change in any of the groups. Thus, the Selank psychotropic effect on animal behavior was markedly dependent on the phase of the annual cycle. A selective effect of Selank on animal behavior was found exclusively in the spring and autumn periods, at a time when hibernating animals exhibit an imbalance in monoaminergic systems [175].

The effects of Noopept and Selank on inhibitory synaptic transmission in hippocampal CA1 pyramidal cells were investigated using the patch-clamp technique in whole-cell configuration. Bath application of Noopept (1 $\mu \mathrm{M})$ or Selank $(2 \mu \mathrm{M})$ significantly increased the frequency of spike-dependent spontaneous mIPSCs, whereas spike-independent mIPSCs remained unchanged. It was suggested that the effect of both peptides was mediated by the activation of inhibitory interneurons terminating on CA1 pyramidal cells. The results of recent clamp recording in inhibitory interneurons residing in the stratum radiatum confirmed this suggestion, at least for Noopept [176].

\subsubsection{Immunomodulatory Effect}

Compared with the original tuftsin molecule, the effect of the final product, Selank, on the immune system is weaker; however, this peptide has a strong and long-lasting impact on the CNS [148,177].

The antiviral activity of Selank against the influenza A virus $\left(\mathrm{H}_{3} \mathrm{~N}_{2}\right)$ was studied using in vitro and in vivo systems. Both systems revealed the presence of an antiviral effect for the drug. The introduction of Selank in vivo induced the expression of the Ifn $\alpha$ gene, without affecting the expression of the Il4, Il10, and Tnfa genes. The mechanism underlying the antiviral action of Selank is probably linked to its ability to modulate the balance of the Th1/Th2 cytokines $[178,179]$.

In the clinic, it was shown that Selank completely inhibited IL6 gene expression (elevated IL6 mRNA levels were observed in patients suffering from neurological diseases) in patients with generalized anxiety disorder and neurasthenia, whereas it had no significant effect on 
the expression of this gene in healthy patients. An in vivo study found no marked induction of cytokines after Selank administration. The adequacy of the immune response to antigenic stimulus was determined by the balance between cell-mediated (Th1) and humoral (Th2) responses. Significant change in the Th1/Th2 balance was observed in both groups of patients. The lymphocytic index decreased significantly as a result of Selank therapy. In contrast, Selank had the opposite effect on the index of monocytes. The dynamics of these changes exhibited a significant inverse correlation, which clearly implies the development of a series of defense reactions aimed both at preventing the negative effects of interferons on the nervous tissue and at preserving the active cell-mediated immune responses [180].

Studies have shown that glyprolines have a specific physiological action. Thus, it is supposed that synthetic regulatory peptides, such as Semax and Selank, have hybrid physiological properties that combine the properties of their structural components [181]. The study of the antiviral properties of the structural fragments of the Selank peptide allowed the selection of Gly-Pro as the minimum amino acid sequence (pharmacophore) that had a pronounced antiviral effect. Among the fragments of Selank studied, the tetrapeptide Arg-Pro-Gly-Pro exhibited the highest antiviral activity against the human influenza $\mathrm{A} / \mathrm{Aichi} / 68$ virus $\left(\mathrm{H}_{3} \mathrm{~N}_{2}\right)$, the human influenza $\mathrm{B} / \mathrm{Ohio} 01 / 05$ virus, the avian influenza virus $\left(\mathrm{H}_{5} \mathrm{~N}_{1}\right)$, the herpes simplex virus types 1 and 2 (HSV-1 and HSV-2), the cytomegalovirus (CMV), and the murine encephalomyocarditis virus (EMCV) [182].

\subsection{Pharmacokinetics}

Primary biodegradation of Selank occurs under the influence of the dipeptidyl carboxypeptidases, which are responsible for the formation of the pentapeptide ThrLys-Pro-Arg-Pro and the longest-lasting tripeptide ThrLys-Pro and dipeptides Arg-Pro and Gly-Pro; these peptides seem to have largely Selank-like effects. The subsequent decay continues until the degradation to individual amino acids, the fate of which in the body is no different to that of the naturally occurring amino acids [183].

Selank evenly labeled with tritium was used to compare the distribution of its metabolites in tissues of rats after intraperitoneal and intranasal administration. Peptides were detected in the bloodstream from the first minute after administration of the drug using both methods. Subsequently, the peptide content decreases rapidly, by more than one-third at $7 \mathrm{~min}$ after intraperitoneal injection of the drug and by half after intranasal administration of the drug, because of their rapid degradation and distribution. The content of Selank and its metabolites in most organs after intranasal administration of the drug was significantly lower than that observed after intraperitoneal injection. The content of Selank in the brain after intranasal administration was comparable to that observed in the blood, remained quite stable, and declined more slowly than it did in the blood and in the organs of the abdominal cavity. In vitro experiments revealed that the half-life of Selank is $\sim 2$ min [183].

Thus, intranasal administration of Selank elicits rapid penetration of the drug into the blood-brain barrier (which allows the use of low dosages) and high bioavailability ( $92.8 \%$ of active substance), and contributes to the rapid onset of clinical effects: it is detected in the plasma $30 \mathrm{~s}$ after administration and is observed in brain tissues 2 min after administration. Selank accumulates in the archicortex and diencephalon (target areas of the actions of Selank) and acts continuously for 20 - $24 \mathrm{~h}$ [183].

\subsection{Effect of Selank on the Transcriptome}

As noted earlier, Inozemtseva et al. found an effect of Selank on Bdnf gene expression in the hippocampus of rats. Administration of Selank at doses of 250 and 500 $\mu \mathrm{g} / \mathrm{kg}$ increased the levels of the Bdnf mRNA $3 \mathrm{~h}$ after injection and the levels of the BDNF protein $24 \mathrm{~h}$ after injection at both doses [169].

Kolomin et al. studied the effect of Selank on gene transcription in the rat hippocampus using cDNA microarrays (SBC-R-RC-100-13 Rat 12K cDNA v.1.3; Shanghai BioChip, China). The microarrays contained 11,060 sequences that were homologous to the rat transcriptome. Selank administration led to a change in mRNA content (by 2 or more times) of 50 genes. Concomitantly, administration of a single intranasal dose of Selank $(200 \mu \mathrm{g} / \mathrm{kg})$ changed the mRNA levels of 36 genes, and a curative administration of Selank (200 $\mu \mathrm{g} / \mathrm{kg}$ once a day for 5 days) changed the mRNA levels of 20 genes. The expression level of six genes (Actn1, Cx3cr1, Fgf7, Kng1, Ptprn2, and Slc6a20) changed after both single and curative introduction of Selank [184].

Genes that exhibited altered expression in the hippocampus of rats by more than 2-fold were clustered according to the structure and biologic functions of their encoded proteins using the bioinformatics software DAVID [185]. These molecules were allocated to three interrelated and overlapping clusters. First, the largest cluster comprised 33 genes that encode proteins embedded in the plasma membranes of cells or their organelles: Actn1, Arfgap1, Atp5a1, Bcam, Cacna1g, Clcnka, Cnksr2, Cx3cr1, Cxcl12, Gldn, Gpr1, Gpr85, Gria4, Grid2, Kcnj4, Lyn, Map2k1, Npr2, P2ry4, Pla2g16, Ptprn2, Scamp5, Scn3b, Selp, Slc1a2, Slc5a7, Slc6a20, Slc8a3, Smad3, Tomm20, Trpc1, Ugt1a6, and Unc13c. Of these, 24 encode transmembrane proteins exclusively (ion channels, transporters of ions and biologic molecules, and transmembrane receptors involved in the 
processes of accumulation and transfer of energy): Bcam, Cacna1g, Clcnka, Cx3cr1, Gldn, Gpr1, Gpr85, Gria4, Grid2, Kcnj4, Npr2, P2ry4, Pla2g16, Ptprn2, Scamp5, Scn3b, Selp, Slc1a2, Slc5a7, Slc6a20, Slc8a3, Tomm20, $\operatorname{Trpc1}$, and Ugt1a6.

The second cluster included nine genes that encode proteins associated with the membranes of neurons and their processes: Actn1, Cacna1g, Gria4, Map2k1, Kcnj4, Klhl24, Ptprn2, Sipa1l1, and Slc1a2.

The third cluster included 15 genes encoding proteins involved in the cellular transport system: Arfgap1, Atp5a1, Cacna1g, Clcnka, Gria4, Grid2, Kcnj4, Scamp5, Scn3b, Slc1a2, Slc5a7, Slc6a20, Slc8a3, Trpc1, and Tomm20. Of these, 10 are involved exclusively in ion transport and ion homeostasis for cell support: Atp5a1, Cacna1g, Clcnka, Gria4, Grid2, Kcnj4, Scn3b, Slc5a7, Slc8a3, and Trpc1 $[184,187]$.

The basic mechanism underlying the transmission of signals, the formation of the action and resting potentials, and the implementation of the phenomenon of long-term potentiation and depression, which play a key role in learning and memory formation, is a change in the level of the balance of the intracellular $\mathrm{Ca}^{2+}$ ion [188]. Maintenance of ion homeostasis by the cell, primarily via ion channels and ion transporters.

The recent study showed that the most notable increase in mRNA level after the curative administration of Selank was in the $S l c 8 a 3$ gene (by 4.2 times), which encodes the NCX3 transporter; NCX3 plays a key role in maintaining the sodium-calcium homeostasis of cells. This vector provides a pathway for the introduction or removal of calcium and sodium, depending on their intracellular concentration. It was previously shown that NCX3 is directly connected to the formation of an action potential in cells of the hippocampus, plays a crucial role in the formation of synaptic plasticity, and exerts neuroprotective effects via the activation of the Akt/PKB signaling pathway. NCX3 is characterized by high-speed transport of sodium and calcium ions across the membrane and plays an important role in restoring the ionic balance disruption that results from ischemic brain damage [189].

Changes in the level of mRNA were observed for genes encoding glutamate and choline transporters. After the administration of a single Selank dose, Slc1a2 was downregulated 2.6-fold. This gene encodes a high-affinity glutamate transporter that ensures the proper transmission of nerve impulses via the removal of glutamate from the synaptic cleft [190]. Curative Selank administration led to a decrease (by 2.9-fold) in the mRNA levels of the $S l c 5 a 7$ gene, which encodes a highly specific choline transporter that is responsible for the delivery of choline to acetylcholine-synthesizing neurons [191].

Increased mRNA levels after both single and curative
Selank introduction were noted for the Slc6a20 gene, which encodes the $\mathrm{Na}^{+}-$and $\mathrm{Cl}^{-}$-dependent proline transporter that facilitates the reabsorption of proline in the renal tubules. According to data from the literature, the carrier is highly expressed in microglia, the choroid plexus, and the meninges. The authors suggest that this transporter is involved in the supply of proline required for collagen synthesis, which is present in large quantities in these structures, and may play a significant role in the reconstruction of the central nervous system after it has been damaged. Conversely, the expression of this gene in the brain regulates the extracellular concentration of proline in the CNS $[192,193]$.

A peculiar response to single and curative Selank administration was observed for the $C \times 3 c r 1$ gene, which encodes a particular protein associated with the G-protein-coupled receptor for fractalkine: a 2-fold decrease in $C \times 3 c r 1$ mRNA levels was observed after a single injecttion of Selank, whereas an increase of almost 3 -fold was detected after curative administration. Fractalkine has adhesive and migratory effects on white blood cells (monocytes and NK cells) and participates in the adhesion of $\mathrm{T}$ cells and macrophages to the endothelium. Fractalkine (CX3CL1) and its receptor (CX3CR1) are predominantly expressed in the brain and exhibit tissuespecific expression patterns: fractalkine is expressed mainly in neurons, and its receptor is expressed predominantly in microglia, which suggests that these two proteins participate in the interaction between neurons and microglia during the process of inflammation [194, 195]. The interaction of the receptors of these cells with fractalkine leads to the induction of the antiapoptotic pathway via the activation of NF-kB and Act kinases and contributes to neuroprotection [196].

Thus, that study showed that both single and curative administration of Selank alters the expression of genes involved in the maintenance of ion homeostasis in cells and the formation of the action potential and nerve impulse transmission, and ensures the processes of synaptic plasticity. These data suggest that the indirect effect of Selank on gene expression has a modulatory effect on the processes that occur in the CNS and are associated with learning and memory formation, and has a positive therapeutic effect in restoring the function of brain cells that were damaged or lost as a result of ischemic or neurodegenerative insults [187].

The expression of five genes (Actn1, Cx3cr1, Fgf7, Ptprn2, and Slc6a20) that were altered in the rat hippocampus was analyzed via real-time PCR after the administration of Selank to the several the brain regions using the schemes described above. The changes in the mRNA levels of these genes exhibited a similar pattern in the frontal cortex and cerebellum, which, in most cases, was different from the pattern observed in the hippo- 
campus. An increase in Slc6a20 mRNA levels was observed in the rat hippocampus and frontal cortex after both single and curative administration of Selank. Significantly higher levels of the $C \times 3 c r 1$ mRNA were detected in the frontal cortex and cerebellum after a single Selank injection, whereas multidirectional changes in the mRNA level of this gene were observed in these regions of the brain after curative administration of the peptide. In the rat cerebellum, a significant decrease was observed in the mRNA levels of the Ptprn2 gene, which is widely expressed in the brain and is involved in the growth and differentiation of nerves [184].

Together with its anxiolytic and nootropic actions, Selank elicits a pronounced immunomodulatory activity $[179,180]$. Previously, it was shown that Selank administration to the rat brain leads to changes in the levels of the $C \times 3 c r 1$ mRNA, which encodes a chemokine receptor involved in the promotion of the immune response. The immunomodulatory effects of Selank may be due to its ability to regulate the immune system at the level of the transcriptome. It was shown that $C x 3 c r 1$ gene expression after Selank introduction is considerably stronger in the rat spleen than it is in the brain. The strongest increase in mRNA levels was observed after a single injection of the peptide (by 16-fold) [184].

This may indicate a more active influence of Selank on gene expression in the spleen. Because the spleen plays a prominent role in ensuring the protective function of the body, such a Selank action may alter the expression levels of genes that are actively involved in the immune response and in major inflammatory reactions.

The expression of genes that are directly involved in the process of inflammation in the spleen of mice under the influence of Selank and some of its fragments should be assessed in future studies.

Three Selank fragments were selected for analysis: the natural regulatory peptide tuftsin, with a macrophageactivating effect, the Arg-Pro-Gly-Pro peptide, which exhibited the largest antiviral activity, and the dipeptide Gly-Pro, which is the smallest structural Selank unit that retains antiviral activity [182]. Selank and its fragments caused changes in the expression of 35 genes involved in inflammation (chemokines, cytokines, and their receptors) in the mouse spleen at $6 \mathrm{~h}$ and $24 \mathrm{~h}$ after a single intraperitoneal injection of the drug. The greatest number of genes with significant mRNA level changes was observed at $24 \mathrm{~h}$ after Selank injection. In contrast, Gly-Pro led to significant changes in the mRNA levels of the greatest number of genes at $6 \mathrm{~h}$ after injection. Changes in the levels of mRNA of the greatest number of genes encoding chemokines were observed at $6 \mathrm{~h}$ after administration of Gly-Pro and tuftsin and 1 day after the introduction of Selank [197,198]. It is known that the fragments of regulatory peptides have their own specific physiological effects. "Hybrid" synthetic peptides combine different physiological effects of the individual fragments [181].

A similar significant decrease in the level of the Cxcl12 mRNA (by an average of 1.3 times) was observed at $6 \mathrm{~h}$ after the administration of Gly-Pro, ArgPro-Gly-Pro, and tuftsin. The $\mathrm{Ccr} 2$ and $\mathrm{Ccr} 4$ genes encode chemokine receptors that are upregulated after the introduction of the dipeptide Gly-Pro. A decrease in the mRNA level of the Xcrl gene was observed 1 day after the administration of each of the peptides; this gene encodes the receptor of lymphotactins. A significant drop in Itgam mRNA levels (by an average of 50 times) was observed $6 \mathrm{~h}$ after the administration of Gly-Pro, ArgPro-Gly-Pro, and tuftsin, whereas a decline in the mRNA of the gene (by 2 times) was detected 1 day after the introduction of Gly-Pro. There was a marked increase in the expression of the gene encoding the interferon gamma (Ifng; by 1.2 times) at $6 \mathrm{~h}$ after injection of Selank and tuftsin. A significant drop in the levels of the mRNA of the $I l 1 r 2$ gene (by 14-fold) was observed $6 \mathrm{~h}$ after Selank injection, and an increase in the level of the mRNA of the gene (by 4.5 times) was detected 1 day after the administration of the peptide. In addition, a decline in the expression of the gene (by 11-fold) was noted $6 \mathrm{~h}$ after the administration of Gly-Pro, whereas its upregulation (by 3 times) was observed 1 day after the introduction of tuftsin. The $I l 2 r g$ gene, which encodes a subunit of a common receptor of various interleukins, was characterized by a drop in the level of its mRNA $6 \mathrm{~h}$ after the administration of each of the peptides [198].

Thus, the administration of Selank and all of its fragments has a significant influence on the levels of expression of the mRNAs of genes encoding chemokines, cytokines, and their receptors. Moreover, the activation of some of them occurs even at 1 day after a single injection of the peptides. As is well known, the adequacy of the immune response to an antigenic stimulus is determined by the balance of cell-mediated (Th1) and humoral (Th2) responses. Moreover, Selank and tuftsin increasingly led to changes in the expression of cytokines that are characteristic of the immune response to specific cell type, whereas the introduction of Gly-Pro altered the expression of genes involved in the humoral immune response. Thus, we can assume that the mechanism underlying the antiviral action of Selank is based on its ability to modulate the balance between Th1 and Th2 cytokines [197].

Changes in the mRNA levels of selected genes were observed more frequently after the introduction of GlyPro, and the activation of most of them was noted as early as $6 \mathrm{~h}$ after injection of the peptide. Thus, we can assume that the minimum fragment of Selank that plays a pharmacophore role is the dipeptide Gly-Pro [187].

Among several other genes that are involved in in- 
flammation, it should be noted that a significant decrease in the expression of the Casp 1 gene, which encodes caspase 1 , was observed $6 \mathrm{~h}$ after the administration of each of the peptides; in addition, an increase in its mRNA levels was detected 1 day after the injection of Selank and tuftsin. Changes in the expression of this gene may contribute to alterations in the population of cytokines and the maintenance of a balance of different types of cells. Similar changes were observed in the expression of the C3 gene, which encodes one of the components of the complement system: downregulation of its mRNA after the administration of each of the peptides under investigation [197].

The Bcl6 gene, which encodes a nuclear sequencespecific transcriptional repressor that plays a key role in the formation and development of the immune system, exhibited significant changes in its expression levels in response to injection of each of the peptides. It should be noted that after the administration of Selank, changes in the mRNA levels of this gene were observed at both $6 \mathrm{~h}$ and $24 \mathrm{~h}$ (by 4.0 and 8.3 times, respectively) after a single injection of the peptide. The strongest decline in Bcl6 mRNA levels was observed at $6 \mathrm{~h}$ after tuftsin administration (by 25 times) and at 1 day after Gly-Pro and Arg-Pro-Gly-Pro injection (by 5.3- and 16.7-fold, respectively). Evaluation of the temporal dynamics of Bcl6 gene expression in the mouse spleen revealed a complex multidirectional change of its mRNA levels after administration of Selank and its fragments. A change in the levels of mRNA of the gene that was equal in value but in the opposite direction was observed $90 \mathrm{~min}$ and $3 \mathrm{~h}$ after Selank injection. The introduction of Gly-Pro led to a significant decrease in Bcl6 mRNA levels at all-time points. Introduction of tuftsin and Arg-Pro-Gly-Pro had a negligible effect on Bcl6 gene expression. Such wavelike changes in Bcl6 gene expression may be associated with maintaining the balance between Th1 and Th2 cells [197].

Thus, a possible mechanism of Selank action lies in its ability, and the ability of its metabolites, to elicit a cumulative effect on the expression of genes involved in various biologic processes. The long-term effects of Selank (stable changes in some genes, even 1 day after a single injection of the peptide) may be due to the fact that Selank and its metabolites act on certain specific recaptors that trigger a cascade of chemical reactions, which maintain the necessary level of the original signal over a long period.

\subsection{Clinical Application}

\subsubsection{Generalized Anxiety Disorder and Neurasthenia}

Anxiety disorders represent a significant medical and socioeconomic problem, and are among the most common presentations in the population of individuals with disorders related to mental activity. Anxiety disorders are accompanied by deterioration of the quality of life, social and occupational maladjustment, and, finally, disability [199-203].

Neznamov et al. conducted a clinical and pharmacological study of the drug "Selank $0.15 \%$ " in patients with a simple structure of anxiety and anxiety-asthenic disorders and in patients with complex anxiety-phobic and anxious-hypochondriac disorders. The administration of the solution "Selank $0.15 \%$ " at a daily dose of $2700 \mu \mathrm{g}$ as early as 1 - 3 days after the beginning of therapy led to a rapid reduction of anxiety, emotional and muscular tension, and anxious thought, as well as improvement of mood, the appearance of vigor, increase in the total tone, and significant reduction in fatigue in patients with generalized anxiety disorders and neurasthenia. A decrease in irritability, sleep disorders, and the algic component of anxiety (tension headaches and body aches) was also noted. Normalization of sleep and a decrease in the severity of autonomic disorders were also observed [204].

In patients with a complex structure of anxiety disorders (anxiety-phobic and anxious-hypochondriac disorders), the drug elicited a gradual reduction of symptoms and fragmentation, with a predominant decrease in anxiety and irritability. Weakening of asthenic symptoms and drowsiness were detected, to a lesser extent, and reflected the stimulatory component of Selank. The manifestations of more complex disorders remained nearly intact [205].

It should be noted that the implementation of a therapeutic regimen of Selank in patients with anxiety-asthenic disorders exhibits specific features. Two variants of therapeutic dynamics of the state were observed after administration of the drug: 1) rapid and concomitant reduction of the full range of psychiatric disorders with critical dynamics in $40 \%$ of patients, and 2) gradual (lytic) regression of symptoms in $60 \%$ of patients. At the critical dynamics more often in patients with neurasthenia, after the first dose there was a rapid decrease in the concordant whole range of psychopathological disordersthe severity of anxiety and emotional stress, combined with the rise of mood, energy, higher general physical tone, and normalization of sleep [205].

Estimates of the in vitro rate of hydrolysis of labeled Leu-enkephalin in the serum of patients showed that the pretreatment value of $\tau 1 / 2$ of the peptide in patients with generalized anxiety disorder was significantly lower than that observed in healthy controls and was correlated with disease duration. Selank treatment results in an increase in the mean Leu-enkephalin $\tau 1 / 2$ in the serum of all patients. An increase in this parameter occurs mainly in patients with generalized anxiety disorder, whereas an 
increase in the Leu-enkephalin $\tau 1 / 2$ value in the serum of patients with neurasthenia as a result of Selank treatment occurs in only half of the cases. This is because the structure of the leading states in generalized anxiety disorder includes symptoms of anxiety and neurasthenia-asthenic disorders, and the spectrum of the drug is determined primarily by the anxiolytic effect [206,207].

\subsubsection{Cognitive Disorders of Organic Origin}

Teleshova et al. studied the neurometabolic properties of Selank in elderly patients with disorders of vascular origin that are psychoorganic to the presence of clinical neurosis and cognitive disorders, suggesting a possible future deliberate application of Selank to the treatment of cognitive disorders of organic genesis. The drug was applied intranasally to patients over the age of 50 years at a dose of $2700 \mu \mathrm{g}$ per day over 14 days.

The effect of Selank became noticeable from the first days of therapy in the form of reduced internal stress, irritability, and anxiety, and the appearance of vigor, improved mood, and increased resistance to stress. Patients became lively and their facial expressions acquired vitality and diversity. There was a decrease in asthenic manifestations. After 2 weeks of treatment, the majority of patients exhibited an improvement regarding the ability to concentrate and reduced forgetfulness.

The analysis of formalized data on the dynamics of psychiatric symptoms in the patients studied indicated the presence of significant changes under the influence of Selank regarding performance anxiety, irritability, fatigability, and apathy. It also revealed positive dynamics in sleep disorders, muscle hypotonia, and orthostatic disorders. These results indicate that the anxiolytic effect of Selank is combined with psychoactive effects, which results in a reduction of asthenic disorders and normalization of mental activity.

There was a positive influence of Selank on the psychophysiological state of patients with this pathology, in the form of an increase in the speed of sensorimotor reactions, and improvement in the parameters of attention and in the level of short-term visual memory. In contrast to the typical action of psychostimulants, the increase in the reaction rate was accompanied by improvement in the quality of these characteristics of their performance, which is typical of neurometabolic drugs.

These results suggest complex neurometabolic, anxiolytic, and stimulating activities for Selank, which result in the reduction of asthenic disorders and normalization of mental activity. The high efficacy of the drug, together with a significant increase in its effectiveness with increased duration of the therapy, was demonstrated. These data suggest that longer courses of therapy are required to achieve a more pronounced effect of Selank [208].

\section{Conclusions}

According to the results of preclinical and clinical studies of Semax and Selank, it can be concluded that both peptides are safe and highly effective, and that drugs derived from them are effective for the treatment of patients with different pathologies of the CNS, as well as for the prevention of these diseases and of increasing stress in healthy people. However, given that the full spectrum of the biologic activity and mechanisms of action of these peptides is not fully understood, it can be assumed that the therapeutic potential of drugs derived from Semax and Selank has not been exhausted.

Intensive research efforts have been aimed at studying the influence of Semax on pathological conditions that are not associated with damage to the nervous system. For example, experiments conducted by using laboratory animals have shown a positive effect of Semax on the course of acute pancreatitis in rats. A single intraperitoneal injection of the drug at a dose of $100 \mu \mathrm{g} / \mathrm{kg}$ reduced the mortality rate of animals, hyperfermentation, the activation of lipid peroxidation, and vascular permeability, and improved microcirculation and accelerated the healing of the zones of destruction of the pancreas [209]. The study of the effects of Semax on various models of ulceration showed a marked antiulcer effect of the drug [210-212].

Investigation of the effect of Semax on the hemostatic system revealed that the peptide interacts with high-molecular-weight heparin, which leads to the formation of a complex compound with anticoagulant and fibrinolytic properties in conditions in vitro, and in vivo when administered intravenously. The authors suggest that Semax, especially in combination with heparin, may be a promising antithrombotic agent [213]. Repeated intranasal administration of Semax at a dose of $1000 \mu \mathrm{g} / \mathrm{kg}$ in a hypercoagulation state caused by immobilization stress of varying degrees yielded a powerful protective antistress effect, which stimulated the anticoagulation system [214].

Volodina et al. have shown that the administration of Semax (23 days at a dose of $50 \mu \mathrm{g} / \mathrm{kg}$ ) to neonatally isolated rats, which led to long-term changes in animal behavior, significantly reduced the negative effects of neonatal stress [215]. Thus, these results may serve as a basis for extending the clinical use of the drug, particularly among children in the early postnatal period.

The analysis of the results obtained in experiments performed by using animals suggests a possible positive effect of Semax in the treatment of diseases such as attention deficits accompanied by hyperactivity and Rett syndrome [216].

Extensive research of Selank also showed that, in addition to the above-described properties, the peptide ex- 
hibits several other characteristics. In various experimental models of gastric ulcers, Selank and its derivatives had a significant antiulcer effect by increasing the resistance of the gastric mucosa to the factors that contributed to the formation of ulcers. This represented an application as a prophylactic drug, and also a pronounced therapeutic effect regarding the formation and treatment of ulcers. The study showed that the most potent antiulcer effect of Selank and its fragment was observed for the hexapeptide Lys-Pro-Arg-Pro-Gly-Pro [217-219].

Selank and its biologic degradation products also have anticoagulant, fibrin-depolymerization, and antiplatelet properties, and do not cause bleeding complications, even in the case of an overdose. Therefore, together with its use as an anxiolytic and nootropic drug for the treatment of generalized anxiety disorder and neurasthenia, Selank can also be used to improve the rheological properties of the blood in many cardiovascular diseases, cerebral circulatory disorders, diabetes, and atherosclerosis [220].

The direction and specificity of the peptides described regarding the cellular transcriptome raise the possibility of using this machinery as a pharmacological target for the normalization of the function of cellular structures in various pathological conditions.

\section{Acknowledgements}

This study was supported in part by the Russian Foundation for Basic Research grant 13-04-01582 and 13-0440083-H; the Russian Academy of Sciences programs: "Molecular and Cellular Biology", "Basic Sciences for Medicine", "Mechanisms of integration of molecular systems in the implementation of the physiological functions"; the Leading Scientific Schools supporting programs-SS_4294.2012.4, SS_2628.2012.4; Governmental contract (agreement \#8851).

\section{REFERENCES}

[1] D. de Wied, "Neuropeptides and Behavior," Nederlands Tijdschrift voor Geneeskunde, Vol. 118, No. 49, 1974, pp. 1865-1869.

[2] J. M. Polak, "Regulatory Peptide," Birkhäuser, Basel, 1988.

[3] I. P. Ashmarin and M. F. Obukhova, "Regulatory Peptides. A functional Continuum," Biokhimiya, Vol. 51, No. 4, 1986, pp. 531-545.

[4] I. P. Ashmarin and M. F. Obukhova, "Current State of the Hypothesis on Functional Continuum of Regulatory Peptides," Vestnik Rossiiskoi Akademii Meditsinskikh Nauk, Vol. 10, 1994, pp. 28-34.

[5] I. P. Ashmarin and S. V. Koroleva, "Rules of Interactions and Functional Continuum of Neuropeptides (On the Way to the Common Conception)," Vestnik Rossiiskoi Akademii
Meditsinskikh Nauk, Vol. 6, 2002, pp. 40-48.

[6] S. V. Koroleva and I. P. Ashmarin, "A Functional Continuum of Regulatory Anxiety-Enhancing Peptides. The Search for Complexes Providing the Optimal Basis for Developing Inhibitory Therapeutic Agents," Neuroscience and Behavioral Physiology, Vol. 36, No. 2, 2006, pp. 157-162. http://dx.doi.org/10.1007/s11055-005-0174-2

[7] O. A. Gomazkov, "Physiologically Active Peptides: A Reference Guide,” Institut Pendidikan Guru Malaysia, Cyberjaya, 1995.

[8] I. P. Ashmarin and P. V. Stukalov, "Neurochemistry," Institute of Biomedical Chemistry, Russian Academy of Medical Sciences, Moscow, 1996.

[9] I. P. Ashmarin and E. P. Karazeeva, "Neuropeptides," In: I. P. Ashmarin, Ed., Biochemestry of the Brain, Saint Petersburg State University, Saint Petersburg, 1999, pp. 232-266.

[10] I. P. Ashmarin, V. N. Nezavibatko, N. G. Levitskaia, V. B. Koshelev and A. A. Kamenskii, "Design and Investigation of an ACTH (4-10) Analogue Lacking D-Amino Acids and Hydrophobic Radicals," Neuroscience Research Communications, Vol. 16, No. 2, 1995, pp. 105112.

[11] I. P. Asmarin, V. N. Nezavibat'ko, N. F. Miasoedov, A. A. Kamenskii, I. A. Grivennikov, M. A. Ponomareva-Stepnaia, L. A. Andreeva, A. Ya Kaplan, V. B. Koshelev and T. V. Riasina, "A Nootropic Adrenocorticotropin Analog 4-10-Semax (15 Years Experience in Its Design and Study)," Zhurnal Vyssher Nervnoŭ Deiatelnosti Imeni ip Pavlova, Vol. 47, No. 2, 1997, pp. 420-430.

[12] I. P. Ashmarin, E. P. Karazeeva, L. A. Lyapina and G. E. Samonina, "The Simplest Proline-Containing Peptides PG, GP, PGP, and GPGG: Regulatory Activity and Possible Sources of Biosynthesis," Biochemistry, Vol. 63, No. 2, 1998, pp. 119-124.

[13] I. P. Ashmarin, "Glyprolines in Regulatory Tripeptides," Neurochemical Journal, Vol. 1, No. 3, 2007, pp. 173-175. http://dx.doi.org/10.1134/S1819712407030014

[14] A. N. Eberle, "Structure and Chemistry of the Peptide Hormones of the Intermediate Lobe," Ciba Foundation Symposium, Vol. 81, 1981, pp. 13-31. http://dx.doi.org/10.1002/9780470720646.ch3

[15] R. E. Mains, B. A. Eipper and N. Ling, "Common Precursor to Corticotropins and Endorphins," Proceedings of the National Academy of Sciences of the United States of America, Vol. 74, No. 7, 1977, pp. 3014-3018. http://dx.doi.org/10.1073/pnas.74.7.3014

[16] V. A. Tkachuk, "Introduction to Molecular Endocrinology," Moscow State University, Moscow, 1983.

[17] I. A. Mirsky, R. Miller and M. Stein, "Relation of Adrenocortical Activity and Adaptive Behavior," Psychosomatic Medicine, Vol. 15, No. 6, 1953, pp. 574-588.

[18] J. V. Murphy and R. E. Miller, "The Effect of Adrenocorticotrophic Hormone (ACTH) on Avoidance Conditioning in the Rat," Journal of Comparative \& Physiological Psychology, Vol. 48, No. 1, 1955, pp. 47-49. http://dx.doi.org/10.1037/h0043004

[19] D. de Wied, "Inhibitory Effect of ACTH and Related 
Peptides on Extinction of Conditioned Avoidance Behavior in Rats," Proceedings of the Society for Experimental Biology and Medicine, Vol. 122, No. 1, 1966, pp. 28-32. http://dx.doi.org/10.3181/00379727-122-31042

[20] B. Bohus and E. Endroeczi, "The Influence of PituitaryAdrenocortical Function on the Avoiding Conditioned Reflex Activity in Rats," Acta Physiologica Academiae Scientiarum Hungaricae, Vol. 26, 1965, pp. 183-189.

[21] B. Bohus and E. Endroeczi, "Regulation of Adrenocortical Steroid Synthesis and Adrenal Tissue Proliferation," Acta Physiologica Academiae Scientiarum Hungaricae, Vol. 28, No. 2, 1965, pp. 125-131.

[22] I. P. Ashmarin, A. A. Kamenskii and S. L. Shelekhov, "Effect of a Fragment of Adrenocorticotropic Hormone (ACTH4-10) on Learning in White Rats Given Positive Reinforcement," Doklady Akademii Nauk SSSR, Vol. 240, No. 5, 1978, pp. 1245-1247.

[23] R. F. McGivern, G. Rose, C. Berka, A. N. Clancy, C. A. Sandman and B. E. Beckwith, "Neonatal Exposure to a High Level of ACTH4-10 Impairs Adult Learning Performance," Pharmacology Biochemistry and Behavior, Vol. 27, No. 1, 1987, pp. 133-142.

http://dx.doi.org/10.1016/0091-3057(87)90487-4

[24] R. N. Glebov and T. V. Goriacheva, "ACTH as a Neuropeptide. The Functional Role of ACTH in the Brain," Patologicheskaia Fiziologiia I Èksperimental'Naia Terapiia, Vol. 4, 1990, pp. 54-57.

[25] L. V. Antonova and A. A. Kamensky, "Pharmacological Activity of ACTH Fragments," In: A. V. Valdman, Ed., Pharmacology of the Neuropeptide, St. Petersburg, 1982. pp. 125-147.

[26] T. B. van Wimersma Greidanus and D. de Wied, "Effects of Systemic and Intracerebral Administration of Two Opposite Acting ACTH-Related Peptides on Extinction of Conditioned Avoidance Behavior," Neuroendocrinology, Vol. 7, No. 5-6, 1971, pp. 291-301. http://dx.doi.org/10.1159/000121977

[27] V. M. Vinogradov, V. I. Medvedev, A. T. Grechko, V. D. Bakharev and M. A. Ponomareva-Stepnaia, "Effect of Neuropeptide Fragments of Adrenocorticotropic Hormone and Vasopressin on the Behavioral Activity of Rats," Fiziologicheskiu Zhurnal SSSR Imeni I. M. Sechenova, Vol. 66, No. 3, 1980, pp. 409-415.

[28] I. P. Ashmarin, "Strong- and Rapid-Action Regulator Peptides," Patologicheskaia Fiziologiia i Èksperimental'Naia Terapiia, Vol. 3, 1988, pp. 3-8.

[29] E. L. Zager and P. M. Black, "Neuropeptides in Human Memory and Learning Processes," Neurosurgery, Vol. 17, No. 2, 1985, pp. 355-369.

http://dx.doi.org/10.1227/00006123-198508000-00023

[30] M. Maurelli, E. Marchioni, F. Savoldi and A. Tartara, "Electroencephalographic, Behavioral and Autonomic Effects of Various ACTH Fragments in Rabbits," Farmaco (Edizione Scientifica), Vol. 42, No. 1, 1987, pp. 33-41.

[31] G. L. Kovacs and D. de Wied, "Peptidergic Modulation of Learning and Memory Processes," Pharmacological Reviews, Vol. 46, No. 3, 1994, pp. 269-291.

[32] J. F. Lois, H. J. Fischer, J. M. Mirra and A. S. Gomes,
"Angiography of Histopathologic Variants of Synovial Sarcoma," Acta Radiologica: Diagnosis, Vol. 27, No. 4, 1986, pp. 449-454.

[33] E. C. Azmitia and E. R. de Kloet, "ACTH Neuropeptide Stimulation of Serotonergic Neuronal Maturation in Tissue Culture: Modulation by Hippocampal Cells," Progress in Brain Research, Vol. 72, 1987, pp. 311-318. http://dx.doi.org/10.1016/S0079-6123(08)60217-4

[34] C. Richter-Landsberg and B. Jastorff, "The Role of cAMP in Nerve Growth Factor-Promoted Neurite Outgrowth in PC12 cells," Journal of Cell Biology, Vol. 102, No. 3, 1986, pp. 821-829. http://dx.doi.org/10.1083/jcb.102.3.821

[35] F. L. Strand and T. T. Kung, "ACTH Accelerates Recovery of Neuromuscular Function Following Crushing of Peripheral Nerve," Peptides, Vol. 1, No. 2, 1980, pp. 135138. http://dx.doi.org/10.1016/0196-9781(80)90077-7

[36] W. H. Gispen and H. Zwiers, "Behavioral and Neurochemical Effects of ACTH," In: W. H. Gispen, Ed., Neurochemistry, Springer-Verlag, New York, 1985, pp. 375412. http://dx.doi.org/10.1007/978-1-4684-7018-5 17

[37] P. Girlanda, U. Muglia, G. Vita, R. Dattola, M. Santoro, A. Toscano, C. Venuto, M. L. Roberto, A. Baradello, M. Romano and C. Messina, "Effect of ACTH4-10 on Nerve Fiber Regeneration after Sciatic Nerve Crush in Rabbits: An Electrophysiological and Morphological Study," Experimental Neurology, Vol. 99, No. 2, 1988, pp. 454-460. http://dx.doi.org/10.1016/0014-4886(88)90162-8

[38] E. M. Hol, W. H. Gispen and P. R. Bar, "ACTH-Related Peptides: Receptors and Signal Transduction Systems Involved in Their Neurotrophic and Neuroprotective Actions," Peptides, Vol. 16. No. 5, 1995, pp. 979-993. http://dx.doi.org/10.1016/0196-9781(95)00017-E

[39] R. Smolnik, B. Perras, M. Molle, H. L. Fehm and J. Born, "Event-Related Brain Potentials and Working Memory Function in Healthy Humans after Single-Dose and Prolonged Intranasal Administration of Adrenocorticotropin 4-10 and Desacetyl-Alpha-Melanocyte Stimulating Hormone," Journal of Clinical Psychopharmacology, Vol. 20, No. 4, 2000, pp. 445-454.

http://dx.doi.org/10.1097/00004714-200008000-00009

[40] H. M. Greven and D. de Wied, "The Influence of Peptides Derived from Corticotrophin (ACTH) on Performance. Structure Activity Studies," Progress in Brain Research, Vol. 39, 1973, pp. 429-442.

http://dx.doi.org/10.1016/S0079-6123(08)64098-4

[41] M. Fekete and D. de Wied, "Potency and Duration of Action of the ACTH 4-9 Analog (ORG 2766) as Compared to ACTH 4-10 and [D-Phe7] ACTH 4-10 on Active and Passive Avoidance Behavior of Rats," Pharmacology, Biochemistry and Behavior, Vol. 16, No. 3, 1982, pp. 387392. http://dx.doi.org/10.1016/0091-3057(82)90439-7

[42] M. Fekete and D. de Wied, "Dose-Related Facilitation and Inhibition of Passive Avoidance Behavior by the ACTH 4-9 Analog (ORG 2766)," Pharmacology, Biochemistry and Behavior, Vol. 17, No. 2, 1982, pp. 177-182. http://dx.doi.org/10.1016/0091-3057(82)90066-1

[43] M. Fekete, B. Bohus, L. van Wolfswinkel, J. M. van Ree and D. de Wied, "Comparative Effects of the ACTH 4-9 
analogue (ORG 2766), ACTH 4-10 and [D-Phe7] ACTH 4-10 on Medial Septal Self-Stimulation Behaviour in Rats," Neuropharmacology, Vol. 21, No. 9, 1982, pp. 909-916. http://dx.doi.org/10.1016/0028-3908(82)90083-1

[44] P. de Koning, J. P. Neijt, F. G. Jennekens and W. H. Gispen, "Org.2766 Protects from Cisplatin-Induced Neurotoxicity in Rats," Experimental Neurology, Vol. 97, No. 3, 1987, pp. 746-750. http://dx.doi.org/10.1016/0014-4886(87)90132-4

[45] F. J. Hock, H. J. Gerhards, G. Wiemer, P. Usinger and R. Geiger, "Learning and Memory Processes of an ACTH4-9 Analog in Mice and Rats," Peptides, Vol. 9, No. 3, 1988, pp. 575-581.

http://dx.doi.org/10.1016/0196-9781(88)90167-2

[46] K. R. Siegfried, "First Clinical Impressions with an ACTH Analog (HOE 427) in the Treatment of Alzheimer's Disease," Annals of the New York Academy of Sciences, Vol. 640, 1991, pp. 280-283.

[47] P. E. Vos, G. J. Bluemink, G. Wolterink and J. M. van Ree, "The ACTH-(4-9) Analogue ORG 2766 Facilitates Denervation Supersensitivity after a Unilateral 6-OHDA Lesion of the Corpus Striatum in Rats," Neuropeptides, Vol. 19, No. 4, 1991, pp. 271-279. http://dx.doi.org/10.1016/0143-4179(91)90094-Y

[48] G. Wolterink, J. M. van Ree, J. W. van Nispen and D. de Wied, "Structural Modifications of the ACTH-(4-9) Analog ORG 2766 Yields Peptides with High Biological Activity," Life Sciences, Vol. 48, No. 2, 1991, pp. 155-161. http://dx.doi.org/10.1016/0024-3205(91)90409-5

[49] M. J. Attella, S. W. Hoffman, M. P. Pilotte and D. G. Stein, "Effects of BIM-22015, an Analog of ACTH4-10, on Functional Recovery after Frontal Cortex Injury," Behavioral and Neural Biology, Vol. 57, No. 2, 1992, pp. 157-166. http://dx.doi.org/10.1016/0163-1047(92)90665-Q

[50] M. A. Ponomareva-Stepnaia, E. A. Porunkevich, A. A. Skuin'sh, V. N. Nezavibat'ko and I. P. Ashmarin, "Hormonal Activity of the ACTH(4-10) Analog-A Prolonged-Action Stimulant of Learning," Bulletin of Experimental Biology and Medicine, Vol. 101, No. 3, 1986, pp. 267-268. http://dx.doi.org/10.1007/BF00835912

[51] E. R. Safarova, S. I. Shram, Y. A. Zolotarev and N. F. Myasoedov, "Effect of Semax Peptide on Survival of Cultured Rat Pheochromocytoma Cells during Oxidative Stress," Bulletin of Experimental Biology and Medicine, Vol. 135, No. 3, 2003, pp. 268-271. http://dx.doi.org/10.1023/A:1024141232307

[52] T. P. Storozhevykh, G. R. Tukhbatova, Y. E. Senilova, V. G. Pinelis, L. A. Andreeva and N. F. Myasoyedov, "Effects of Semax and Its Pro-Gly-Pro Fragment on Calcium Homeostasis of Neurons and Their Survival under Conditions of Glutamate Toxicity," Bulletin of Experimental Biology and Medicine, Vol. 143, No. 5, 2007, pp. 601604. http://dx.doi.org/10.1007/s10517-007-0192-x

[53] I. A. Grivennikov, O. V. Dolotov and Iu. I. Gol'dina, "Peptide Factors in Processes of Proliferation, Differentiation, and Extended Viability of Mammalian Nervous System Cells," Molecular Biology, Vol. 33, No. 1, 1999, pp. 120-126.
[54] I. A. Grivennikov, O. V. Dolotov, Y. A. Zolotarev, L. A. Andreeva, N. F. Myasoedov, L. Leacher, I. B. Black and C. F. Dreyfus, "Effects of Behaviorally Active ACTH (4-10) Analogue-Semax on Rat Basal Forebrain Cholinergic Neurons," Restorative Neurology and Neuroscience, Vol. 26, No. 1, 2008, pp. 35-43.

[55] A. Y. Kaplan, V. B. Koshelev, V. N. Nezavibatko and I. P. Ashmarin, "The Increase of Resistance to Hypoxia by Using Neuropeptide Drug Semax," Human physiology, Vol. 18, No. 5, 1992, pp. 104-107.

[56] M. V. Maslova, Ia. V. Krushinskaia, A. S. Maklakova, P. V. Balan, Iu. B. Kuznetsov, N. A. Sokolova and I. P. Ashmarin, "Effect of Heptapeptide Semax on the Cardiac Activity in Acute Hypobaric Hypoxia during the Early Postnatal Period," Bulletin of Experimental Biology and Medicine, Vol. 128, No. 2, 1999, pp. 797-799. http://dx.doi.org/10.1007/BF02433818

[57] V. V. Iasnetsov and T. A. Voronina, "Antihypoxic and Antiamnesic Effects of Mexidol and Semax," EksperiMental'Naia i Klinicheskaia Farmakologiia, Vol. 73, No. 4, 2010, pp. 2-7.

[58] V. V. Iasnetsov and T. A. Voronina, "Effect of Semax and Mexidol on Brain Ischemia Models in Rats," Eksperimental'Naia i Klinicheskaia Farmakologiia, Vol. 72, No. 1, 2009, pp. 68-70.

[59] V. K. Khugaeva and V. V. Aleksandrin, "Relationship between the Therapeutic Effect of the Peptide Preparation Semax and the Severity of Brain Ischemia," Bulletin of Experimental Biology and Medicine, Vol. 124, No. 1, 1997, pp. 655-658. http://dx.doi.org/10.1007/BF02445053

[60] O. E. Fadiukova, A. A. Alekseev, V. G. Bashkatova, I. A. Tolordava, V. S. Kuzenkov, V. D. Mikoian, A. F. Vanin, V. B. Koshelev and K. S. Raevskiŭ, "Semax Prevents Elevation of Nitric Oxide Generation Caused by Incomplete Global Ischemia in the Rat Brain," Eksperimental'Naia $i$ Klinicheskaia Farmakologiia, Vol. 64, No. 2, 2001, pp. 31-34.

[61] V. G. Bashkatova, V. B. Koshelev, O. E. Fadyukova, A. A. Alexeev, A. F. Vanin, K. S. Rayevsky, I. P. Ashmarin and D. M. Armstrong, "Novel Synthetic Analogue of ACTH 4-10 (Semax) but not Glycine Prevents the Enhanced Nitric Oxide Generation in Cerebral Cortex of Rats with Incomplete Global Ischemia," Brain Research, Vol. 894, No. 1, 2001, pp. 145-149. http://dx.doi.org/10.1016/S0006-8993(00)03324-2

[62] G. A. Romanova, D. N. Silachev, F. M. Shakova, Y. N. Kvashennikova, I. V. Viktorov, S. I. Shram and N. F. Myasoedov, "Neuroprotective and Antiamnesic Effects of Semax during Experimental Ischemic Infarction of the Cerebral Cortex," Bulletin Experimental Biology and Medicine, Vol. 142, No. 6, 2006, pp. 663-666. http://dx.doi.org/10.1007/s10517-006-0445-0

[63] D. N. Silachev, S. I. Shram, F. M. Shakova, G. A. Romanova and N. F. Miasoedov, "Formation of the Spatial Memory in Rats with Ischemic Injury in Prefrontal Areas of the Cortex; Effects of a Sinthetic Analogue of ACTH(47)," Neuroscience and Behavioral Physiology, Vol. 39, No. 8, 2008, pp. 749-756. http://dx.doi.org/10.1007/s11055-009-9197-4 
[64] A. N. Gerenko, V. N. Nezavibatko, A. V. Volkov and A. A. Kamenskii, "Motor Activity of Rats in the Postresuscitation Period," Moscow University Biological Sciences Bulletin, Vol. 3, 1991, pp. 24-30.

[65] F. I. Volkov, Y. V. Zarzhetsky, A. Y. Postnov, G. K. Bolyakina, A. A. Kamensky and O. B. Muraviov, "The Results of Regulatory Peptide Administration during Reanimation after Cardioplegia," Terminal Condition and Resuscitation Pathology of the Body: Pathophysiology, Clinical Features, Prevention and Treatment, Scientific Research Institute of General Reanimatology RAMS, Moscow, 1992, pp. 69-76.

[66] G. V. Alekseeva, N. A. Bottaev and V. V. Goroshkova, "Use of Semax at a Follow-Up of Patients with Posthypoxic Encephalopathy," Anesteziologiia I Reanimatologiia, Vol. 1, 1999, pp. 40-43.

[67] O. V. Dolotov, E. A. Karpenko, T. S. Seredenina, L. S. Inozemtseva, N. G. Levitskaya, Y. A. Zolotarev, A. A. Kamensky, I. A. Grivennikov, J. Engele and N. F. Myasoedov, "Semax, an Analogue of Adrenocorticotropin (4-10), Binds Specifically and Increases Levels of Brain-Derived Neurotrophic Factor Protein in Rat Basal Forebrain," Journal of Neurochemistry, Vol. 97, No. 1, 2006, pp. 82-86.

http://dx.doi.org/10.1111/j.1471-4159.2006.03658.x

[68] T. V. V'yunova, K. V. Shevchenko, V. P. Shevchenko, M. Y. Bobrov, V. V. Bezuglov and N. F. Myasoedov, "Specific Binding of Semax in Different Regions of the Rat Brain," Doklady Biological Sciences, Vol. 410, No. 1, 2006, pp. 376-377. http://dx.doi.org/10.1134/S0012496606050085

[69] M. I. Shadrina, O. V. Dolotov, I. A. Grivennikov, P. A. Slominsky, L. A. Andreeva and L. S. Inozemtseva, "Rapid Induction of Neurotrophin mRNAs in Rat Glial Cell Cultures by Semax, an Adrenocorticotropic Hormone Analog," Neuroscience Letters, Vol. 308, No. 2, 2001, pp. 115108. http://dx.doi.org/10.1016/S0304-3940(01)01994-2

[70] O. V. Dolotov, T. S. Seredenina, N. G. Levitskaya, A. A. Kamensky, L. A. Andreeva, L. Y. Alfeeva, I. Y. Nagaev, Y. A. Zolotarev, I. A. Grivennikov, Y. Engele and N. F. Myasoedov, "The Heptapeptide SEMAX Stimulates BDNF Expression in Different Areas of the Rat Brain in Vivo," Doklady Biological Sciences, Vol. 391, No. 1-6, 2003, pp. 292-295. http://dx.doi.org/10.1023/A:1025177812262

[71] O. V. Dolotov, E. A. Karpenko, L. S. Inozemtseva, T. S. Seredenina, N. G. Levitskaya, J. Rozyczka, E. V. Dubynina, E. V. Novosadova, L. A. Andreeva, L. Y. Alfeeva, A. A. Kamensky, I. A. Grivennikov, N. F. Myasoedov and J. Engele, "Semax, an Analog of ACTH(4-10) with Cognitive Effects, Regulates BDNF and trkB Expression in the Rat Hippocampus," Brain Research, Vol. 1117, No. 1, 2006, pp. 54-60. http://dx.doi.org/10.1016/j.brainres.2006.07.108

[72] T. Y. Agapova, Y. V. Agniullin, M. I. Shadrina, S. I. Shram, P. A. Slominsky, S. A. Lymborska and N. F. Myasoedov, "Neurotrophin Gene Expression in Rat Brain under the Action of Semax, an Analogue of ACTH 4-10," Neuroscience Letters, Vol. 417, No. 2, 2007, pp. 201-205. http://dx.doi.org/10.1016/j.neulet.2007.02.042

[73] V. V. Stavchansky, V. V. Yuzhakov, A. Y. Botsina, V. I.
Skvortsova, L. N. Bondurko, M. G. Tsyganova, S. A. Limborska, N. F. Myasoedov and L. V. Dergunova, "The Effect of Semax and Its C-End Peptide PGP on the Morphology and Proliferative Activity of Rat Brain Cells during Experimental Ischemia: A Pilot Study," Journal of Molecular Neuroscience, Vol. 45, No. 2, 2011, pp. 177185. http://dx.doi.org/10.1007/s12031-010-9421-2

[74] D. M. Manchenko, N. Glazova, N. G. Levitskaia, L. A. Andreeva, A. A. Kamenskii and N. F. Miasoedov, "Nootropic and Analgesic Effects of Semax Following Different Routes of Administration," Rossiǔskii Fiziologicheskiu Zhurnal Imeni I.M. Sechenova, Vol. 96, No. 10, 2010, pp. 1014-1023.

[75] V. N. Potaman, L. Y. Alfeeva, A. A. Kamensky, N. G. Levitzkaya and V. N. Nezavibatko, "N-terminal Degradation of ACTH(4-10) and Its Synthetic Analog Semax by the Rat Blood Enzymes," Biochemical Biophysical Research Communications, Vol. 176, No. 2, 1991, pp. 741746. http://dx.doi.org/10.1016/S0006-291X(05)80247-5

[76] V. N. Potaman, L. Y. Alfeeva, A. A. Kamensky and V. N. Nezavibatko, "Degradation of ACTH/MSH(4-10) and Its Synthetic Analog Semax by Rat Serum Enzymes: An Inhibitor Study," Peptides, Vol. 14, No. 3, 1993, pp. 491495. http://dx.doi.org/10.1016/0196-9781(93)90137-6

[77] E. A. Sebentsova, A. V. Denisenko, N. G. Levitskaia, L. A. Andreeva, A. A. Kamenskii and N. F. Miasoedov, "Long-Lasting Behavioral Effects of Chronic Neonatal Treatment with ACTH (4-10) Analogue Semax in White Rat Pups," Zhurnal Vysshě Nervnoŭ Deiatelnosti Imeni ip Pavlova, Vol. 55, No. 2, 2005, pp. 213-220.

[78] E. A. Sebentsova, N. Glazova, N. G. Levitskaia, L. A. Andreeva, L. Alfeeva, A. A. Kamenskii and N. F. Miasoedov, "Dependence of Long-Lasting Effects of the ACTH(4-10) Analogue Semax on the Time of Its Neonatal Administration," Rossiǔskii Fiziologicheskiu Zhurnal Imeni I.M. Sechenova, Vol. 91, No. 2, 2005, pp. 122-131.

[79] A. Y. A. Kaplan, A. G. Kochetova, V. N. Nezavibatko, T. V. Rjasina and I. P. Ashmarin, "Synthetic ACTH Analogue Semax Displays Nootropic-Like Activity in Human," Neuroscience Research Communications, Vol. 19, No. 2, 1996, pp. 115-123.

http://dx.doi.org/10.1002/(SICI)1520-6769(199609)19:2< 115::AID-NRC171>3.0.CO;2-B

[80] P. E. Umryukhin, K. V. Anokhin and K. S. Raevskii, "Dizocilpine Blocks the Effects of Delta Sleep-Inducing Peptide-Induced Suppression of C-Fos Gene Expression in the Paraventricular Nucleus of the Hypothalamus in Rats," Neuroscience and Behavioral Physiology, Vol. 34, No. 5, 2004, pp. 501-503. http://dx.doi.org/10.1023/B:NEAB.0000022637.57852.e0

[81] K. V. Sudakov, P. E. Umryukhin, E. V. Koplik and K. V. Anokhin, "Expression of the C-Fos Gene during Emotional Stress in Rats: The Clocking Effect of Delta SleepInducing Peptide," Neuroscience and Behavioral Physiology, Vol. 31, No. 6, 2001, pp. 635-640. http://dx.doi.org/10.1023/A:1012381413726

[82] D. A. Vilenskii, N. G. Levitskaia, L. A. Andreeva, L. Alfeeva, A. A. Kamenskii and N. F. Miasoedov, "Effects of Chronic Semax Administration on Exploratory Activity and Emotional Reaction in White Rats," Rossiǔskii 
Fiziologicheskiü Zhurnal Imeni I.M. Sechenova, Vol. 93, No. 6, 2007, pp. 661-669.

[83] N. G. Levitskaia, D. A. Vilenskii, E. A. Sebentsova, L. A. Anreeva, A. A. Kamenskii and N. F. Miasoedov, "Influence of Semax on the Emotional State of White Rats in the Norm and against the Background of CholecystokininTetrapeptide Action," Biology Bulletin, Vol. 37, No. 2, 2010, pp. 186-192. http://dx.doi.org/10.1134/S1062359010020147

[84] K. O. Eremin, V. S. Kudrin, P. Saransaari, S. S. Oja, I. A. Grivennikov, N. F. Myasoedov and K. S. Rayevsky, "Semax, an ACTH(4-10) Analogue with Nootropic Properties, Activates Dopaminergic and Serotoninergic Brain Systems in Rodents," Neurochemical Research, Vol. 30, No. 12, 2005, pp. 1493-1500. http://dx.doi.org/10.1007/s11064-005-8826-8

[85] D. M. Ivanova, N. G. Levitskaya, L. A. Andreeva, A. A. Kamenskii and N. F. Myasoedov, "Comparative Study of Analgesic Potency of ACTH4-10 Fragment and Its Ana$\log$ Semax," Bulletin of Experimental Biology and Medicine, Vol. 143, No. 1, 2007, pp. 5-8. http://dx.doi.org/10.1007/s10517-007-0002-5

[86] E. B. Arushanian and A. V. Popov, "Chronotropic Activity of Semax," Eksperimental'Naia i Klinicheskaia FarMakologiia, Vol. 71, No. 2, 2008, pp. 14-16.

[87] K. O. Eremin, V. S. Kudrin, I. A. Grivennikov, N. F. Miasoedov and K. S. Rayevsky, "Effects of Semax on Dopaminergic and Serotoninergic Systems of the Brain," Doklady Biological Sciences, Vol. 394, No. 1-6, 2004, pp. $1-3$.

[88] K. O. Eremin, P. Saransaari, S. Oja and K. S. Raevskii, "Semax Potentiates Effects of D-Amphetamine on the Level of Extracellular Dopamine in the Sprague-Dawley Rat Striatum and on the Locomotor Activity of C57BL/6 Mice," Eksperimental'Naia i Klinicheskaia Farmakologiia, Vol. 67, No. 2, 2004, pp. 8-11.

[89] Y. A. Zolotarev, S. E. Zhuikova, I. P. Ashmarin, N. F. Myasoedov, B. V. Vas'kovskii and G. E. Samonina, "Metabolism of PGP Peptide after Administration via Different Routes," Bulletin of Experimental Biology and Medicine, Vol. 135, No. 4, 2003, pp. 361-364.

http://dx.doi.org/10.1023/A:1024612831380

[90] O. V. Dolotov, Iu. A. Zolotarev, E. M. Dorokhova, L. A. Andreeva, L. Alfeeva, I. A. Grivennikov and N. F. Myasoedov, "The Binding of Semax, ACTH 4-10 Heptapeptide, to Plasma Membranes of the Rat Forebrain Basal Nuclei and Its Biodegradation," Russian Journal of Bioorganic Chemistry, Vol. 30, No. 3, 2004, pp. 213-217. http://dx.doi.org/10.1023/B:RUBI.0000030127.46845.f0

[91] Y. A. Zolotarev, O. V. Dolotov, L. S. Inozemtseva, A. K. Dadayan, E. M. Dorokhova, L. A. Andreeva, L. Y. Alfeeva, I. A. Grivennikov and N. F. Myasoedov, "Degradation of the ACTH(4-10) Analog Semax in the Presence of Rat Basal Forebrain Cell Cultures and Plasma Membranes," Amino Acids, Vol. 30, No. 4, 2006, pp. 403-408. http://dx.doi.org/10.1007/s00726-006-0328-8

[92] K. V. Shevchenko, I. Y. Nagaev, L. Y. Alfeeva, L. A. Andreeva, A. A. Kamenskii, N. G. Levitskaia, V. P. Shevchenko, I. A. Grivennikov and N. F. Miasoedov, "Ki- netics of Semax Penetration into the Brain and Blood of Rats after Its Intranasal Administration," Russian Journal of Bioorganic Chemistry, Vol. 32, No. 1, 2006, pp. 57-62. http://dx.doi.org/10.1134/S1068162006010055

[93] N. G. Levitskaya, E. A. Sebentsova, N. Glazova, O. G. Voskresenskaya, L. A. Andreeva, L. Alfeeva, A. A. Kamenskii and N. F. Miasoedov, "Study on the Neurotropic Activity of the Products of Semax Enzymatic Degradation," Doklady Biological Sciences, Vol. 372, No. 1, 2000, pp. 243-246.

[94] V. N. Potaman, L. V. Antonova, V. A. Dubynin, D. A. Zaitzev, A. A. Kamensky, N. F. Myasoedov and V. N. Nezavibatko, "Entry of the Synthetic ACTH(4-10) Analogue into the Rat Brain Following Intravenous Injection," Neuroscience Letters, Vol. 127, No. 1, 1991, pp. 133-136. http://dx.doi.org/10.1016/0304-3940(91)90912-D

[95] T. Agapova, Ia. V. Agniullin, D. N. Silachev, M. I. Shadrina, P. A. Slominskii, S. I. Shram, S. A. Limborskaia and N. F. Miasoedov, "Effect of Semax on the Temporary Dynamics of Brain-Derived Neurotrophic Factor and Nerve Growth Factor Gene Expression in the Rat Hippocampus and Frontal Cortex," Molekuliarnaia Genetika, Mikrobiologiia I Virusologiia, Vol. 3, 2008, pp. 28-32.

[96] M. Shadrina, T. Kolomin, T. Agapova, Y. Agniullin, S. Shram, P. Slominsky, S. Limborskaia and N. Miasoedov, "Comparison of the Temporary Dynamics of NGF and BDNF Gene Expression in Rat Hippocampus, Frontal Cortex, and Retina Under Semax Action," Journal of Molecular Neuroscience, Vol. 41, No. 1, 2010, pp. 30-35. http://dx.doi.org/10.1007/s12031-009-9270-Z

[97] T. Y. Agapova, Y. V. Agniullin, D. N. Silachev, M. I. Shadrina, P. A. Slominsky, S. I. Shram, S. A. Limborskaia and N. F. Miasoedov, "Expression Changes Caused by the Peptide Semax in the Intracellular Signal Pathway Genes in Rat Hippocamp," Doklady Biochemistry and Biophysics, Vol. 417, No. 1, 2007, pp. 334-336. http://dx.doi.org/10.1134/S1607672907060129

[98] V. G. Dmitrieva, L. V. Dergunova, O. V. Povarova, V. I. Skvortsova, S. A. Limborskaia and N. F. Miasoedov, "The Effect of Semax and the C-Terminal Peptide PGP on Expression of Growth Factor Genes and Receptors in Rats under Conditions of Experimental Cerebral Ischemia," Doklady Biochemistry and Biophysics, Vol. 422, No. 1, 2008, pp. 261-264. http://dx.doi.org/10.1134/S1607672908050037

[99] V. G. Dmitrieva, O. V. Povarova, V. I. Skvortsova, S. A. Limborskaia, N. F. Miasoedov and L. V. Dergunova, "Semax and Pro-Gly-Pro Activate the Transcription of Neurotrophins and Their Receptor Genes after Cerebral Ischemia," Cellular and Molecular Neurobiology, Vol. 30, No. 1, 2010, pp. 71-79. http://dx.doi.org/10.1007/s10571-009-9432-0

[100] V. V. Stavchanskii, T. V. Tvorogova, A. Y. Botsina, V. I. Skvortsova, S. A. Limborskaia, N. F. Miasoedov and L. V. Dergunova, "The Effect of Semax and Its C-Terminal Peptide PGP on Expression of the Neurotrophins and Their Receptors in the Rat Brain during Incomplete Global Ischemia," Molecular Biology, Vol. 45, No. 6, 2011, pp. 941-949.

http://dx.doi.org/10.1134/S0026893311050128 
[101] E. I. Gusev, G. S. Burd, A. B. Gekht, V. I. Skvortsova, M. A. Bogomolova, M. V. Selikhova and S. M. Fidler, "The Clinico-Neurophysiological Study of the Effect of Cerebrolysin on Brain Function in the Acute and Early Recovery Periods of Hemispheric Ischemic Stroke," Zhurnal Nevrologii i Psikhiatrii Imeni S.S. Korsakova, Vol. 94, No.1, 1994, pp. 9-13.

[102] E. I. Gusev, V. I. Skvortsova, A. V. Kovalenko and M. A. Sokolov, "Mechanisms of Brain Tissue Damage in Acute Focal Cerebral Ischemia," Zhurnal Nevrologii i Psikhiatrii Imeni S.S. Korsakova, Vol. 99, No. 2, 1999, pp. 65-70.

[103] V. I. Skvortsova, K. S. Raevskii, A. V. Kovalenko, V. S. Kudrin, L. A. Malikova, M. A. Sokolov, A. A. Alekseev and E. I. Gusev, "Levels of Neurotransmitter Amino Acids in the Cerebrospinal Fluid of Patients with Acute Ischemic Insult," Neuroscience and Behavioral Physiology, Vol. 30, No. 5, 2000, pp. 491-495. http://dx.doi.org/10.1007/BF02462604

[104] V. I. Skvortsova, "Mechanisms of the Damaging Action of Cerebral Ischemia and Neuroprotection," Vestnik Rossiiskoi Akademii Meditsinskikh Nauk, Vol. 11, 2003, pp. 74-80.

[105] E. I. Gusev and V. I. Skvortsova, "Brain Ischemia,” Kluwer Academic/Plenum Publishers, Berlin, 2003.

[106] V. I. Skvortsova, E. L. Nasonov, E. Zhuravleva, I. A. Grivennikov, E. L. Arsen'eva, I. I. Sukhanov, N. F. Miasoedov and E. I. Gusev, "Clinico-Immunobiochemical Monitoring of Factors of Focal Inflammation in the Acute Period of Hemispheric Ischemic Stroke," Zhurnal Nevrologii I Psikhiatrii Imeni S.S. Korsakova, Vol. 99, No. 5, 1999, pp. 27-31.

[107] V. I. Shmyrev, N. V. Mironov, T. J. Zaets, P. V. Vladimirov, M. B. Torshin and A. G. Shestakov, "Efficacy and Tolerance of Semax in Patients with Initial Forms of Cerebrovascular Disease," Kremljovskaya Medicina Clinichsky Vestnik, Vol. 3, 1998, pp. 8-9.

[108] E. I. Gusev, V. I. Skvortsova, N. F. Miasoedov, V. N. Nezavibat'ko, E. Zhuravleva and A. V. Vanichkin, "Effectiveness of Semax in Acute Period of Hemispheric Ischemic Stroke (A Clinical and Electrophysiological Study)," Zhurnal Nevrologii i Psikhiatrii Imeni S.S. Korsakova, Vol. 97, No. 6, 1997, pp. 26-34.

[109] E. I. Gusev, V. I. Skvortsova, G. A. Izykenova, A. A. Alekseev and S. A. Dambinova, "The Level of Autoantibodies to Glutamate Receptors in the Blood Serum of Patients in the Acute Period of Ischemic Stroke," Zhurnal Nevrologii i Psikhiatrii Imeni S.S. Korsakova, Vol. 96, No. 5, 1996, pp. 68-72.

[110] N. F. Miasoedov, V. I. Skvortsova, E. L. Nasonov, E. I. Zhuravleva, I. A. Grivennikov, E. L. Arsen'eva and I. I. Sukhanov, "Investigation of Mechanisms of Neuro-Protective Effect of Semax in Acute Period of Ischemic Stroke," Zhurnal Nevrologii i Psikhiatrii Imeni S.S. Korsakova, Vol. 99, No. 5, 1999, pp. 15-19.

[111] L. L. Bronner, D. S. Kanter and J. E. Manson, "Primary Prevention of Stroke," New England Journal of Medicine, Vol. 333, No. 21, 1995, pp. 1392-1400.

[112] E. G. Stewart-Wynne and K. Jamrozik, "Risk Factors and Primary Prevention of Stroke," Australian and New Zea- land Journal of Medicine, Vol. 25, No. 3, 1995, pp. 191194.

http://dx.doi.org/10.1111/j.1445-5994.1995.tb01519.x

[113] E. I. Gusev, V. I. Skvortsova and E. I. Chukanova, "Semax in Prevention of Disease Progress and Development of Exacerbations in Patients with Cerebrovascular Insufficiency," Zhurnal Nevrologii i Psikhiatrii Imeni S.S. Korsakova, Vol. 105, No. 2, 2005, pp. 35-40.

[114] N. L. Sheremet, G. S. Polunin, A. N. Ovchinnikov, A. A. Kamenskii, N. G. Levitskaia, L. A. Andreeva, L. Iu. Alfeeva and I. Iu. Nagaev, "An Experimental Substantiation for Using the 'Semax' Neuroprotector in the Treatment of Optic-Nerve Diseases," Vestnik Oftalmologii, Vol. 120, No. 6, 2004, pp. 25-27.

[115] N. I. Kurysheva, A. A. Shpak, E. E. Ioileva, L. I. Galanter, N. D. Nagornova, N. Iu. Shubina and N. N. Shlyshalova, "Semax in the Treatment of Glaucomatous Optic Neuropathy in Patients with Normalized Ophthalmic Tone," Vestnik Oftalmologii, Vol. 117, No. 4, 2001, pp. 5-8.

[116] G. S. Polunin, S. M. Nurieva, D. L. Baiandin, N. L. Sheremet and L. A. Andreeva, "Evaluation of Therapeutic Effect of New Russian Drug Semax in Optic Nerve Disease," Vestnik Oftalmologii, Vol. 116, No. 1, 2000, pp. 15-18.

[117] N. N. Osborne, M. Ugarte, M. Chao, G. Chidlow, J. H. Bae, J. P. Wood and M. S. Nash, "Neuroprotection in Relation to Retinal Ischemia and Relevance to Glaucoma," Survey Ophthalmology, Vol. 43, No. 1, 1999, pp. S102-S128. http://dx.doi.org/10.1016/S0039-6257(99)00044-2

[118] M. Schwartz and E. Yoles, "Optic Nerve Degeneration and Potential Neuroprotection: Implications for Glaucoma," European Journal of Ophthalmology, Vol. 9, No. 1, 1999, pp. 9-11.

[119] O. V. Yurova, E. A. Turova, N. E. Morozova, O. A. Rogan and G. A. Nazarova, "Efficiency of Neuroprotective Therapy in the Treatment of Nonproliferative Diabetic Retinopathy," Vestnik Vosstanovitel'Noj Mediciny, Vol. 6, 2011, pp. 35-38.

[120] J. E. Blalock, "The Syntax of Immune-Neuroendocrine Communication," Immunology Today, Vol. 15, No. 11, 1994, pp. 504-511. http://dx.doi.org/10.1016/0167-5699(94)90205-4

[121] V. A. Najjar and K. Nishioka, “Tuftsin': A Natural Phagocytosis Stimulating Peptide," Nature, Vol. 228, No. 5272, 1970, pp. 672-673.

http://dx.doi.org/10.1038/228672a0

[122] G. M. Edelman, B. A. Cunningham, W. E. Gall, P. D. Gottlieb, U. Rutishauser and M. J. Waxdal, "The Covalent Structure of an Entire $\gamma \mathrm{G}$ Immunoglobulin Molecule," Proceedings of the National Academy of Sciences of the United States of America, Vol. 63, No. 1, 1969, pp. 78-85. http://dx.doi.org/10.1073/pnas.63.1.78

[123] T. J. Lukas, H. Munoz and B. W. Erickson, "Inhibition of C1-Mediated Immune Hemolysis by Monomeric and Dimeric Peptides from the Second Constant Domain of Human Immunoglobulin G," Journal of Immunology, Vol. 127, No. 6, 1981, pp. 2555-2560.

[124] K. Nishioka, A. A. Amoscato, G. F. Babcock, R. A. 
Banks and J. H. Phillips, "Tuftsin: An Immunomodulating Peptide Hormone and Its Clinical Potential as a Natural Biological Response Modifier," Cancer Investigation, Vol. 2, No. 1, 1984, pp. 39-49.

http://dx.doi.org/10.3109/07357908409020285

[125] J. E. Camel, K. S. Kim, G. H. Tchejeyan and G. H. Mahour, "Efficacy of Passive Immunotherapy in Experimental Postsplenectomy Sepsis due to Haemophilus influenzae Type B," Journal of Pediatric Surgery, Vol. 28, No. 11, 1993, pp. 1441-1445. http://dx.doi.org/10.1016/0022-3468(93)90427-M

[126] E. S. Caplan, H. Boltansky, M. J. Snyder, J. Rooney, N. J. Hoyt, G. Schiffman and R. A. Cowley, "Response of Traumatized Splenectomized Patients to Immediate Vaccination with Polyvalent Pneumococcal Vaccine," Journal of Trauma, Vol. 23, No. 9, 1983, pp. 801-805. http://dx.doi.org/10.1097/00005373-198309000-00005

[127] J. B. Green, S. R. Shackford, M. J. Sise and R. W. Powell, "Postsplenectomy Sepsis in Pediatric Patients Following Splenectomy for Trauma: A Proposal for a Multi-Institutional Study," Journal of Pediatric Surgery, Vol. 21, No. 12, 1986, pp. 1084-1086. http://dx.doi.org/10.1016/0022-3468(86)90014-X

[128] N. J. Bump, J. Lee, M. Wleklik, J. Reichler and V. A. Najjar, "Isolation and Subunit Composition of Tuftsin Receptor," Proceedings of the National Academy of Sciences of the United States of America, Vol. 83, No. 19, 1986, pp. 7187-7191.

http://dx.doi.org/10.1073/pnas.83.19.7187

[129] M. K. Chaudhuri, D. Konopinska, N. J. Bump and V. A. Najjar, "The Similarity between Tuftsin (Thr-Lys-Pro-Arg) Receptors and Tuftsin Antibody: A Case of Induced Molecular Mimicry," Annals of the New York Academy of Sciences, Vol. 419, 1983, pp. 135-142. http://dx.doi.org/10.1111/j.1749-6632.1983.tb37098.x

[130] E. Cillari, G. Di Gesu, S. Palmeri, D. Lio, A. Salerno, P. Li Voti and M. F. La Via, "Double-Rosetting Technique for the Detection of Fc Gamma Receptor-Positive T Lymphocytes," Diagnostic Immunology, Vol. 1, No. 2, 1983, pp. 80-86.

[131] I. Z. Siemion and D. Konopinska, "Tuftsin Analogs and Their Biological Activity," Molecular and Cellular Biochemistry, Vol. 41, No. 1, 1981, pp. 99-111. http://dx.doi.org/10.1007/BF00225300

[132] W. J. W. Morrow, D. A. Isenberg, R. E. Sobol, R. B. Stricker and T. Kieber-Emmons, "AIDS Virus Infection and Autoimmunity: A Perspective of the Clinical, Immunological, and Molecular Origins of the Autoallergic Pathologies Associated with HIV Disease," Clinical Immunology and Immunopathology, Vol. 58, No. 2, 1991, pp. 163-180. http://dx.doi.org/10.1016/0090-1229(91)90134-V

[133] J. H. Phillips, G. F. Babcock and K. Nishioka, "Tuftsin: A Naturally Occurring Immunopotentiating Factor. I. In Vitro Enhancement of Murine Natural Cell-Mediated Cytotoxicity," Journal of Immunology, Vol. 126, No. 3, 1981, pp. 915-921.

[134] M. S. Wleklik, M. Luczak and V. A. Najjar, "Tuftsin Induced Tumor Necrosis Activity," Molecular and Cellular Biochemistry, Vol. 75, No. 2, 1987, pp. 169-174.
http://dx.doi.org/10.1007/BF00229905

[135] A. V. Valdman, M. M. Kozlovskaia, I. P. Ashmarin, M. F. Mineeva and K. V. Anokhin, "Central Effects of the Tetrapeptide Tuftsin," Bulletin of Experimental Biology and Medicine, Vol. 92, No. 1, 1981, pp. 890-892. http://dx.doi.org/10.1007/BF00836989

[136] Z. S. Herman, Z. Stachura, L. Opielka, I. Z. Siemion and E. Nawrocka, "Tuftsin and D-Arg3-Tuftsin Possess Analgesic Action," Experientia, Vol. 37, No. 1, 1981, pp. 7677. http://dx.doi.org/10.1007/BF01965580

[137] Z. S. Herman, Z. Stachura, I. Z. Siemion and E. Nawrocka, "Analgesic Activity of Some Tuftsin Analogs," Naturwissenschaften, Vol. 67, No. 12, 1980, pp. 613-614. http://dx.doi.org/10.1007/BF00396552

[138]Z. S. Herman, "Pharmacological Effects of Neurotensin, Substance P and Tuftsin," Postepy Biochemii, Vol. 31, No. 3-4, 1985, pp. 487-508.

[139] Z. S. Herman, G. Laskawiec, K. Golba, A. Kubik and I. Z. Siemion, "L-Prolyl-L-Arginine Fragment of Tuftsin Peptide Chain Elicits Analgesic Action," Naturwissenschaften, Vol. 72, No. 2, 1985, pp. 85-86. http://dx.doi.org/10.1007/BF00508137

[140] T. P. Semenova, M. M. Kozlovskaia, E. A. Gromova and A. V. Val'dman, "Characteristics of the Action of Psychostimulants on Learning and Memory in Rats," Bulletin of Experimental Biology and Medicine, Vol. 106, No. 8, 1988, pp. 161-163.

[141] T. P. Semenova, M. M. Kozlovskaia, A. V. Val'dman and E. A. Gromova, "Effect of Tuftsin and Its Analog on Learning, Memory and Exploratory Behavior in Rats," Zhurnal Vysshě Nervnoŭ Deiatelnosti Imeni IP Pavlova, Vol. 38, No. 6, 1988, pp. 1033-1040.

[142] R. Veskov, N. S. Popova, Z. Ostoich, O. S. Adrianov and L. Rakich, "The Effect of the Tetrapeptide Tafcin on the Bioelectrical Activity of Brain Structures in Various Functional States of the Central Nervous System," Bulletin of Experimental Biology and Medicine, Vol. 119, No. 4, 1995, pp. 365-355.

http://dx.doi.org/10.1007/BF02445890

[143] N. S. Popova, L. M. Gershtein, E. L. Dovedova and L. M. Kachalova, "The Correlation of the Behavioral, Bioelectrical and Cytobiochemical Characteristics of the Effect of Taftsin," Zhurnal Vysshě Nervnoi Deiatelnosti Imeni IP Pavlova, Vol. 46, No. 1, 1996, 163-169.

[144] L. M. Gershtein, M. T. Dobrynina and A. V. Sergutina, "Morphochemical Changes in Brain Structures in the Course of Chronic Haloperidol Treatment and the Correction of these Changes with Tuftsin," Molecular and Chemical Neuropathology, Vol. 30, No. 3, 1997, 213-222. http://dx.doi.org/10.1007/BF02815099

[145] G. P. Semenova, E. V. Gurevich, M. M. Kozlovskaia and E. A. Gromova, "The Role of the Brain Monoaminergic Systems in the Effects of Tuftsin and Its Analog on Animal Emotional Behavior," Fiziologicheskii Zhurnal SSSR Imeni I.M. Sechenova, Vol. 75, No. 6, 1989, pp. 759-765.

[146] K. V. Sudakov, "Oligopeptides in the Mechanisms of Resistance to Emotional Stress," Patologicheskaia Fiziologiia I Eksperimentalnaia Terapiia, Vol. 1, 1989, pp. 3-11.

[147] M. M. Kozlovskaya, I. I. Kozlovskii, E. A. Val'dman and 
S. B. Seredenin, "Selank and Short Peptides of the Tuftsin Family in the Regulation of Adaptive Behavior in Stress," Neuroscience and Behavioral Physiology, Vol. 33, No. 9, 2003, pp. 853-860. http://dx.doi.org/10.1023/A:1025988519919

[148] R. Czabak-Garbacz, B. Cygan, L. Wolanski and I. Kozlovsky, "Influence of Long-Term Treatment with Tuftsin Analogue TP-7 on the Anxiety-Phobic States and Body Weight," Pharmacological Reports, Vol. 58, No. 4, 2006, pp. 562-567.

[149] T. N. Sollertinskaya, M. V. Shorokhov, M. M. Kozloveskaya, I. I. Kozlovskii and K. V. Sudakov, "Compensatory and Antiamnestic Effects of Heptapeptide Selank in Monkeys," Journal of Evolutionary Biochemistry and Physiology, Vol. 44, No. 3, 2008, pp. 332-340. http://dx.doi.org/10.1134/S0022093008030101

[150] S. B. Seredenin, Yu. A. Blednov, B. A. Badyshtov, M. L. Gordey and Y. A. Nagovitsina, "Pharmacogenetic Analysis of Mechanisms of Emotional Stress: Effects of Benzodiazepines," Annali Dell Istituto Superiore Di Sanita, Vol. 26, No. 1, 1990, pp. 81-87.

[151] S. B. Seredenin, M. M. Kozlovskaia, Iu. A. Blednov, I. I. Kozlovskii, T. P. Semenova, R. Czabak-Garbacz, V. N. Nezavibat'ko and N. F. Miasoedov, "The Anxiolytic Action of an Analog of the Endogenous Peptide Tuftsin on Inbred Mice with Different Phenotypes of the Emotional Stress Reaction," Zhurnal Vysshei Nervnoi Deiatelnosti Imeni I.P. Pavlova, Vol. 48, No. 1, 1998, pp. 153-160.

[152] V. B. Narkevich, V. S. Kudrin, P. M. Klodt, A. A. Pokrovskii, M. M. Kozlovskaia, A. I. Maiskii and K. S. Raevskiǐ, "Effects of Heptapeptide Selank on the Content of Monoamines and Their Metabolites in the Brain of BALB/C and C57B1/6 Mice: A Comparative Study," Eksperimentalnaia $i$ Klinicheskaia Farmakologiia, Vol. 71, No. 5, 2008, pp. 8-12.

[153] I. I. Kozlovskii, L. A. Andreeva, M. M. Kozlovskaia, A. V. Nadorova and L. G. Kolik, "The Role of Opioid System in Peculiarities of Anti-Anxiety Effect of Peptide Anxiolytic Selank," Eksperimentalnaia $i$ Klinicheskaia Farmakologiia, Vol. 75, No. 2, 2012, pp. 10-13.

[154] K. Y. Sarkisova, M. A. Kulikov, I. S. Midzyanovskaya and A. A. Folomkina, "Dopamine-Dependent Nature of Depression-Like Behavior in WAG/Rij Rats with Genetic Absence Epilepsy," Neuroscience and Behavioral Physiology, Vol. 38, No. 2, 2008, pp. 119-128. http://dx.doi.org/10.1007/s11055-008-0017-z

[155] N. V. Kost, O. Sokolov, M. V. Gabaeva, I. A. Grivennikov, L. A. Andreeva, N. F. Miasoedov and A. A. Zozulya, "Semax and Selank Inhibit the Enkephalin-Degrading Enzymes from Human Serum," Russian Journal of Bioorganic Chemistry, Vol. 27, No. 3, 2001, pp. 156-159. http://dx.doi.org/10.1023/A:1011373002885

[156] D. Filliol, S. Ghozland, J. Chluba, M. Martin, H. W. Matthes, F. Simonin, K. Befort, C. Gavériaux-Ruff, A. Dierich, M. LeMeur, O. Valverde, R. Maldonado and B. L. Kieffer, "Mice Deficient for $\delta$ - and $\mu$-Opioid Receptors Exhibit Opposing Alterations of Emotional Responses," Nature Genetics, Vol. 25, No. 2, 2000, pp. 195-200. http://dx.doi.org/10.1038/76061
[157] A. A. Zozulia, V. K. Meshavkin, A. V. Toropov and K. G. Gurevich, "Anxiolytic Effect of Dalargin on Rat Behavior in the Vogel Conflict Test and the Raised Cross-Like Labyrinth," Bulletin of Experimental Biology and Medicine, Vol. 127, No. 2, 1999, 191-193. http://dx.doi.org/10.1007/BF02433112

[158] V. K. Meshavkin, N. V. Kost, O. Y. Sokolov, Y. A. Zolotarev, N. F. Myasoedov and A. A. Zozulya, "NaloxoneBlocked Depriming Effect of Anxiolytic Selank on Apomorphine-Induced Behavioral Manifestations of Hyperfunction of Dopamine System," Bulletin of Experimental Biology and Medicine, Vol. 142, No. 5, 2006, pp. 598600. http://dx.doi.org/10.1007/s10517-006-0428-1

[159] O. Y. Sokolov, V. K. Meshavkin, N. V. Kost and A. A. Zozulya, "Effects of Selank on Behavioral Reactions and Activities of Plasma Enkephalin-Degrading Enzymes in Mice with Different Phenotypes of Emotional and Stress Reactions," Bulletin of Experimental Biology and Medicine, Vol. 133, No. 2, 2002, pp. 133-135.

http://dx.doi.org/10.1023/A:1015582302311

[160] Y. A. Zolotarev, O. Y. Sokolov, N. V. Kost, B. V. Vas'kovskii, N. F. Miasoedov and A. A. Zozulia, "Leu-Enkephalin Homogeneously Labeled with Tritium in Studying the Selank Inhibiting Effect on the Enkephalin-Degrading Enzymes of Human Plasma," Bioorganicheskaia Khimiia, Vol. 30, No. 3, 2004, pp. 234-240.

[161] T. P. Semenova, I. I. Kozlovskii, N. M. Zakharova and M. M. Kozlovskaia, "Comparison of the Effects of Selank and Tuftsin on the Metabolism of Serotonin in the Brain of Rats Pretreated with PCPA," Eksperimentalnaia $i$ Klinicheskaia Farmakologiia, Vol. 72, No. 4, 2009, pp. 6-8.

[162] M. M. Kozlovskaia, S. B. Seredenin, I. I. Kozlovskii, A. V. Valdman, L. A. Andreeva and N. F. Myasoedov, "A Comparative Study of the Effect of Tuftsin Fragments on Passive Avoidance Learning Characteristics," Pharmaceutical Chemistry Journal, Vol. 35, No. 3, 2001, pp. 121-123. http://dx.doi.org/10.1023/A:1010441409246

[163] I. I. Kozlovskii and N. D. Danchev, "The Optimizing Action of the Synthetic Peptide Selank on a Conditioned Active Avoidance Reflex in Rats," Neuroscience and Behavioral Physiology, Vol. 33, No. 7, 2003, pp. 639-643. http://dx.doi.org/10.1023/A:1024444321191

[164] R. Czabak-Garbacz, B. Cygan, I. I. Kozlovskii, “Tuftsin Analog and Behavior of Rabbits after Electric Stimulation of Ventromedial Hypothalamus Nucleus (VMH)," Behavioural Pharmacology, Vol. 7, No. 1, 1996, pp. 22-25. http://dx.doi.org/10.1097/00008877-199605001-00050

[165] T. Esch, G. B. Stefano, G. L. Fricchione and H. Benson, "The Role of Stress in Neurodegenerative Diseases and Mental Disorders," Neuro Endocrinology Letters, Vol. 23, No. 3, 2002, pp. 199-208.

[166] M. Alonso, M. R. M. Vianna, A. M. Depino, T. Mello e Souza, P. Pereira, G. Szapiro, H. Viola, F. Pitossi, I. Izquierdo and J. H. Medina, "BDNF-Triggered Events in the Rat Hippocampus are Required for both Short- and Long-Term Memory Formation," Hippocampus, Vol. 12, No. 4, 2002, pp. 551-560. http://dx.doi.org/10.1002/hipo.10035

[167] L. Minichiello, M. Korte, D. Wolfer, R. Kühn, K. Un- 
sicker, V. Cestari, C. Rossi-Arnaud, H-P. Lipp, T. Bonhoeffer and R. Klein, "Essential Role for TrkB Receptors in Hippocampus-Mediated Learning," Neuron, Vol. 24, No. 2, 1999, pp. 401-414.

http://dx.doi.org/10.1016/S0896-6273(00)80853-3

[168] M. Mizuno, K. Yamada, A. Olariu, H. Nawa and T. Nabeshima, "Involvement of Brain-Derived Neurotrophic Factor in Spatial Memory Formation and Maintenance in a Radial Arm Maze Test in Rats," The Journal of Neuroscience, Vol. 20, No. 18, 2000, pp. 7116-7121.

[169] L. S. Inozemtseva, E. A. Karpenko, O. V. Dolotov, N. G. Levitskaya, A. A. Kamensky, L. A. Andreeva and I. A. Grivennikov, "Intranasal Administration of the Peptide Selank Regulates BDNF Expression in the Rat Hippocampus in Vivo," Doklady Biological Sciences, Vol. 421, No. 1, 2008, pp. 241-243.

http://dx.doi.org/10.1134/S0012496608040066

[170] T. P. Semenova, M. M. Kozlovskaia, N. I. Medvinskaia and I. I. Koslovskii, "Restoration with Heptapeptide (Synthetic Taftsin Derivative) of Cognitive Functions Impaired by Antenatal Hypoxia," Bulletin of Experimental Biology and Medicine, Vol. 125, No. 3, 1998, pp. 289-292.

[171] T. P. Semenova, M. M. Kozlovskaia, A. V. Zuikov, I. I. Kozlovskii, N. M. Zakharova and L. A. Andreeva, "Selank-Induced Normalizing Effects on the Integrative Brain Activity and Biogenic Amine Level Disorders due to Antenatal Hypoxia," Rossiǔskii Fiziologicheskiu Zhurnal Imeni I.M. Sechenova, Vol. 92, No. 11, 2006, pp. 1332-1338.

[172] T. P. Semenova, M. M. Kozlovskaya, N. M. Zakharova, I. I. Kozlovskii and A. V. Zuikov, "Effect of Selank on Cognitive Processes after Damage Inflicted to the Cerebral Catecholamine System during Early Ontogeny," Bulletin of Experimental Biology and Medicine, Vol. 144, No. 5, 2007, pp. 689-691.

[173] I. I. Kozlovskii, Iu. F. Belozertsev, T. P. Semenova, A. V. Zuikov and M. M. Kozlovskaia, "Compensatory Effect of Selank on the Mnestic Functions Disturbed by Neurotoxic Damage of the Noradrenergic System of the Rat Brain," Eksperimental'Naia i Klinicheskaia Farmakologiia, Vol. 71, No. 2, 2008, pp. 3-7.

[174] T. P. Semenova, I. I. Kozlovskii, N. M. Zakharova and M. M. Kozlovskaia, "Experimental Optimization of Learning and Memory Processes by Selank," Eksperimental'Naia $i$ Klinicheskaia Farmakologiia, Vol. 73, No. 8, 2010, pp. 2-5.

[175] T. P. Semenova, M. M. Kozlovskaya, A. V. Zuikov, I. I. Kozlovskii and L. A. Andreeva, "Seasonal Effects of Selank on the Behavior of Hibernating Animals," Bulletin of Experimental Biology and Medicine, Vol. 140, No. 6, 2005, pp. 705-707. http://dx.doi.org/10.1007/s10517-006-0060-0

[176] V. G. Skrebitskii, R. V. Kondratenko, I. S. Povarov and V. I. Derevyagin, "Peptidergic Modulation of Synaptic Activity in the Hippocampus," Neuroscience and Behavioral Physiology, Vol. 43, No. 5, 2013, pp. 650-655. http://dx.doi.org/10.1007/s11055-013-9786-0

[177] T. P. Semenova, M. M. Kozlovskaya, A. V. Zuikov, I. I. Kozlovskii, N. M. Zakharova and L. A. Andreeva, "Use of Selank to Correct Measures of Integrative Brain Activ- ity and Biogenic Amine Levels in Adult Rats Resulting from Antenatal Hypoxia," Neuroscience and Behavioral Physiology, Vol. 38, No. 2, 2008, pp. 203-207. http://dx.doi.org/10.1007/s11055-008-0030-2

[178] F. I. Ershov, P. N. Uchakin, O. N. Uchakina, M. V. Mezentseva, L. A. Alekseeva and N. F. Miasoedov, "Antiviral Activity of Immunomodulator Selank in Experimental Influenza Infection," Voprosy Virusologii, Vol. 54, No. 5, 2009, pp. 19-24.

[179] L. A. Andreeva, M. V. Mezentseva, I. Yu. Nagaev, I. M. Shapoval, V. E. Shcherbenko, L. A. Potapova, L. I. Russu, A. N. Narovlyansky, F. I. Ershov and N. F. Myasoedov, "Ex Vivo Screening of Prospective Peptide Drugs: New Approaches," Doklady Biological Sciences, Vol. 434, No. 1, 2010, pp. 300-303. http://dx.doi.org/10.1134/S0012496610050029

[180] O. N. Uchakina, P. N. Uchakin, N. F. Miasoedov, L. A. Andreeva, V. E. Shcherbenko, M. V. Mezentseva, M. V. Gabaeva, O. Iu. Sokolov, A. A. Zozulia and F. I. Ershov, "Immunomodulatory Effects of Selank in Patients with Anxiety-Asthenic Disorders," Zhurnal Nevrologii i Psikhiatrii Imeni S.S. Korsakova, Vol. 108, No. 5, 2008, pp. 71-75.

[181] I. P. Ashmarin, G. E. Samonina, L. A. Lyapina, A. A. Kamenskiia, N. G. Levitskaya, I. A. Grivennikov, O. V. Dolotov, L.A. Andreeva and N. F. Myasoedov, "Natural and Hybrid ('Chimeric') Stable Regulatory Glyproline Peptides," Pathophysiology, Vol. 11, No. 4, 2005, pp. 179 185. http://dx.doi.org/10.1016/j.pathophys.2004.10.001

[182] L. A. Andreeva, I. Yu. Nagaev, M. V. Mezentseva, I. M. Shapoval, R. Ya. Podchernyaeva, V. E. Shcherbenko, L. A. Potapova, L. I. Russu, F. I. Ershov and N. F. Myasoedov, "Antiviral Properties of Structural Fragments of the Peptide Selank," Doklady Biological Sciences, Vol. 431, No. 1, 2010, pp. 79-82. http://dx.doi.org/10.1134/S0012496610020031

[183] Yu. A. Zolotarev, A. K. Dadayan, O. V. Dolotov, V. S. Kozik and N. F. Myasoedov, "Evenly Tritium-Labeled Peptides and Their in Vivo and in Vitro Biodegradation," Russian Journal of Bioorganic Chemistry, Vol. 32, No. 2, 2006, pp. 166-173. http://dx.doi.org/10.1134/S1068162006020099

[184] T. A. Kolomin, M. I. Shadrina, Ya. V. Agniullin, S. I. Shram, P. A. Slominskii, S. A. Limborska and N. F. Myasoedov, "Transcriptomic Response of Rat Hippocampus and Spleen Cells to Single and Chronic Administration of the Peptide Selank," Doklady Biochemistry and Biophysics, Vol. 430, No. 1, 2010, pp. 5-6. http://dx.doi.org/10.1134/S1607672910010023

[185] G. Dennis, B. T. Sherman, D. A. Hosack, J. Yang, W. Gao, H. C. Lane and R. A. Lempicki, "DAVID: Database for Annotation, Visualization, and Integrated Discovery," Genome Biology, Vol. 4, No. 5, 2003, p. P3. http://dx.doi.org/10.1186/gb-2003-4-5-p3

[186] D. W. Huang, B. T. Sherman and R. A. Lempicki, "Systematic and Integrative Analysis of Large Gene Lists Using DAVID Bioinformatics Resources," Nature Protocols, Vol. 4, No. 1, 2008, pp. 44-57.

[187] S. A. Limborska, T. A. Kolomin, M. I. Shadrina, S. I. Shram, P. A. Slominsky, and N. F. Myasoedov, "Tran- 
scriptome Alteration in Hippocampus and Spleen under the Treatment of Regulative Peptide Selank and Some of Its Fragments," Proceedings of the biology of genomes, Cold Spring Harbor Laboratory Meeting, Cold Spring Harbor, 11-15 May 2010, p. 179.

[188] B. Katz and R. Miledi, "Further Study of the Role of Calcium in Synaptic Transmission," Journal of Physiology, Vol. 207, No. 3, 1970, pp. 789-801.

[189] N. Gabellini, "Transcriptional Regulation by cAMP and $\mathrm{Ca}^{2+}$ Links the $\mathrm{Na}^{+} / \mathrm{Ca}^{2+}$ Exchanger 3 to Memory and Sensory Pathways," Molecular Neurobiology, Vol. 30, No. 1, 2004, pp. 91-116. http://dx.doi.org/10.1385/MN:30:1:091

[190] B. I. Kanner, "Glutamate Transporters from Brain: A Novel Neurotransmitter Transporter Family," FEBS Letters, Vol. 325, No. 1-2, 1993, pp. 95-99. http://dx.doi.org/10.1016/0014-5793(93)81421-U

[191] S. M. Ferguson and R. D. Blakely, "The Choline Transporter Resurfaces: New Roles for Synaptic Vesicles?" Molecular Interventions, Vol. 4, No. 1, 2004, pp. 22-37. http://dx.doi.org/10.1124/mi.4.1.22

[192] A. Dahlin, J. Royall, J.G. Hohmann and J. Wang, "Expression Profiling of the Solute Carrier Gene Family in the Mouse Brain," Journal of Pharmacology and Experimental Therapeutics, Vol. 329, No. 2, 2009, pp. 558-570. http://dx.doi.org/10.1124/jpet.108.149831

[193] H. Takanaga, B. Mackenzie, Y. Suzuki and M. A. Hediger, "Identification of Mammalian Proline Transporter $\mathrm{SIT}_{1}\left(\mathrm{SLC6A}_{20}\right)$ with Characteristics of Classical System Imino," Journal of Biological Chemistry, Vol. 280, No. 10, 2005, pp. 8974-8984. http://dx.doi.org/10.1074/jbc.M413027200

[194] J. K. Harrison, Y. Jiang, S. Chen, Y. Xia, D. Maciejewski, R. K. McNamara, W. J. Streit, M. N. Salafranca, S. Adhikari, D. A. Thompson, P. Botti, K. B. Bacon and L. L. Feng, "Role for Neuronally Derived Fractalkine in Mediating Interactions between Neurons and CX3CR1-Expressing Microglia," Proceedings of the National Academy of Sciences of the United States of America, Vol. 95, No. 18, 1998, pp. 10896-10901. http://dx.doi.org/10.1073/pnas.95.18.10896

[195] A. Nishiyori, M. Minami, Y. Ohtani, S. Takami, J. Yamamoto, N. Kawaguchi, T. Kume, A. Akaike and M. Sato, "Localization of Fractalkine and $\mathrm{CX}_{3} \mathrm{CR} 1$ mRNAs in Rat Brain: Does Fractalkine Play a Role in Signaling from Neuron to Microglia?" FEBS Letters, Vol. 429, No. 2, 1998, pp. 167-172. http://dx.doi.org/10.1016/S0014-5793(98)00583-3

[196] O. Meucci, A. Fatatis, A. A. Simen and R. J. Miller, "Expression of $\mathrm{CX}_{3} \mathrm{CR} 1$ Chemokine Receptors on Neurons and Their Role in Neuronal Survival," Proceedings of the National Academy of Sciences of the United States of America, Vol. 97, No. 14, 2000, pp. 8075-8080. http://dx.doi.org/10.1073/pnas.090017497

[197] T. Kolomin, M. Shadrina, L. Andreeva, P. Slominsky, S. Limborska and N. Myasoedov, "Expression of Inflammation-Related Genes in Mouse Spleen under Tuftsin Analog Selank," Regulatory Peptides, Vol. 170, No. 1-3, 2011, pp. 18-23. http://dx.doi.org/10.1016/j.regpep.2011.05.001
[198] T. A. Kolomin, M. I. Shadrina, P. A. Slominsky, S. A. Limborska and N. F. Myasoedov, "Changes in Expression of the Genes for Chemokines, Cytokines, and Their Receptors in Response to Selank and Its Fragments," Russian Journal of Genetics, Vol. 47, No. 5, 2011, pp. 629-631. http://dx.doi.org/10.1134/S1022795411050103

[199] D. Kessler, K. Lloyd, G. Lewis and D. P. Gray, "Cross Sectional Study of Symptom Attribution and Recognition of Depression and Anxiety in Primary Care," British Medical Journal, Vol. 318, No. 7181, 1999, pp. 436-439. http://dx.doi.org/10.1136/bmj.318.7181.436

[200] R. C. Kessler, R. L. DuPont, P. Berglund and H.-U. Wittchen, "Impairment in Pure and Comorbid Generalized Anxiety Disorder and Major Depression at 12 Months in Two National Surveys," The American Journal of Psychiatry, Vol. 156, No. 12, 1999, pp. 1915-1923.

[201] H.-U. Wittchen, "The Many Faces of Social Anxiety Disorder," International Clinical Psychopharmacology, Vol. 15 , No. 1, 2000, pp. 7-12. http://dx.doi.org/10.1097/00004850-200007001-00003

[202] H-U. Wittchen, R. M. Carter, H. Pfister, S. A. Montgomery and R. C. Kessler, "Disabilities and Quality of Life in Pure and Comorbid Generalized Anxiety Disorder and Major Depression in a National Survey," International Clinical Psychopharmacology, Vol. 15, No. 6, 2000, pp. 319-328. http://dx.doi.org/10.1097/00004850-200015060-00002

[203] H-U. Wittchen, R. C. Kessler, H. Pfister, M. Höfler and R. Lieb, "Why Do People with Anxiety Disorders Become Depressed? A Prospective-Longitudinal Community Study," Acta Psychiatrica Scandinavica, Vol. 102, No. 406, 2000, pp. 14-23. http://dx.doi.org/10.1111/j.0065-1591.2000.acp29-03.x

[204] G. G. Neznamov, E. S. Teleshova, V. K. Bochkarev, V. V. Koschelev and T. S. Syunyakov, "Novel Anxiolytic Selank: Results of Phase II Clinical Trials," European Neuropsychopharmacology, Vol. 15, No. 2, 2005, pp. 159160. http://dx.doi.org/10.1016/S0924-977X(05)80332-3

[205] T. S. Syunyakov, E. S. Teleshova, S. A. Syunyakov and G. G. Neznamov, "The Effect of Novel Anxiolytic Drug Selank on the Psychophysiological Parameters of Patients with Generalized Anxiety Disorder," Proceedings of Traditions and Innovations in Psychiatry: WPA Regional Meeting, St Petersburg, 10-12 June 2010, pp. 22-23.

[206] A. A. Zozulia, G. G. Neznamov, T. S. Siuniakov, N. V. Kost, M. V. Gabaeva, O. Iu. Sokolov, E. V. Serebriakova, O. A. Siranchieva, A. V. Andriushchenko, E. S. Telesheva, S. A. Siuniakov, A. B. Smulevich, N. F. Miasoedov and S. B. Seredenin, "Efficacy and Possible Mechanisms of Action of a New Peptide Anxiolytic Selank in the Therapy of Generalized Anxiety Disorders and Neurasthenia," Zhurnal Nevrologii i Psikhiatrii Imeni S.S. Korsakova, Vol. 108, No. 4, 2008, pp. 38-48.

[207] A. A. Zozulya, N. V. Kost, O. Y. Sokolov, M. V. Gabaeva, I. A. Grivennikov, L. N. Andreeva, Yu. A. Zolotarev, S. V. Ivanov, A. V. Andryushchenko, N. F. Myasoedov and A. B. Smulevich, "The Inhibitory Effect of Selank on Enkephalin-Degrading Enzymes as a Possible Mechanism of Its Anxiolytic Activity," Bulletin of Experimental Biology and Medicine, Vol. 131, No. 4, 2001, pp. 315-317. 
http://dx.doi.org/10.1023/A:1017979514274

[208] E. S. Teleshova, V. K. Bochkarev, T. S. Syunyakov, T. P. Bugaeva and G. G. Neznamov, "Results of Clinical and Pharmacological Studies of Anxiolytic Peptide Selank," Psychiatry, Vol. 4, No. 4, 2010, pp. 26-35.

[209] Y. V. Ivanov and V. V. Iasnetsov, "The Effect of Semax and Mexidol on the Course of Acute Pancreatitis in Rats," Eksperimental'Naia i Klinicheskaia Farmakologiia, Vol. 63, No. 1, 2000, pp. 41-44.

[210] I. O. Ivanikov, M. E. Brekhova, G. E. Samonina, N. F. Myasoedov and I. P. Ashmarin, "Therapy of Peptic Ulcer with Semax Peptide," Bulletin of Experimental Biology and Medicine, Vol. 134, No. 1, 2002, pp. 73-74. http://dx.doi.org/10.1023/A:1020621124776

[211] S. E. Zhuikova, V. I. Sergeev, G. E. Samonina and N. F. Myasoedov, "Possible Mechanism Underlying the Effect of Semax on the Formation of Indomethacin-Induced U1cers in Rats," Bulletin of Experimental Biology and Medicine, Vol. 133, No. 6, 2002, pp. 577-579. http://dx.doi.org/10.1023/A:1020285909696

[212] S. E. Zhuikova, E. A. Smirnova, Z. V. Bakaeva, G. E. Samonina and I. P. Ashmarin, "Effect of Semax on Homeostasis of Gastric Mucosa in Albino Rats," Bulletin of Experimental Biology and Medicine, Vol. 130, No. 3, 2000, pp. 871-873. http://dx.doi.org/10.1007/BF02682256

[213] L. A. Lyapina, V. E. Pastorova, G. E. Samonina and I. P. Ashmarin, "The Effect of Prolil-Glycil-Proline (PGP) Peptide and PGP-Rich Substances on Haemostatic Parameters of Rat Blood," Blood Coagulation and Fibrinolysis, Vol. 11, No. 5, 2000, pp. 409-414. http://dx.doi.org/10.1097/00001721-200007000-00002

[214] M. E. Grigorjeva and L. A. Lyapina, "Anticoagulation and Antiplatelet Effects of Semax under Conditions of Acute and Chronic Immobilization Stress," Bulletin of Experimental Biology and Medicine, Vol. 149, No. 1, 2010, pp. 44-46. http://dx.doi.org/10.1007/s10517-010-0871-x

[215] M. A. Volodina, E. A. Sebentsova, N. Y. Glazova, D. M. Manchenko, L. S. Inozemtseva, O. V. Dolotov, L. A. Andreeva, N. G. Levitskaya, A. A. Kamensky and N. F. Myasoedov, "Correction of Long-Lasting Negative Effects of Neonatal Isolation in White Rats Using Semax," Acta Naturae, Vol. 4, No. 1, 2012, pp. 86-92.

[216] S. J. Tsai, "Semax, an Analogue of Adrenocorticotropin (4-10), Is a Potential Agent for the Treatment of Attention-Deficit Hyperactivity Disorder and Rett Syndrome," Medical Hypotheses, Vol. 68, No. 5, 2007, pp. 1144-1146. http://dx.doi.org/10.1016/j.mehy.2006.07.017

[217] T. S. Pavlov, G. E. Samonina, L. A. Andreeva, N. F. Myasoedov and I. P. Ashmarin, "A New Property of the Synthetic Anxiolytic Selank and Its Derivatives," Doklady Biological Sciences, Vol. 397, No. 1-6, 2004, pp. 281-283. http://dx.doi.org/10.1023/B:DOBS.0000039692.94366.2c

[218] T. S. Pavlov, G. E. Samonina, Z. V. Bakaeva, Y. A. Zolotarev and A. A. Guseva, "Selank and Its Metabolites Maintain Homeostasis in the Gastric Mucosa," Bulletin of Experimental Biology and Medicine, Vol. 143, No. 1, 2007, pp. 51-53.

http://dx.doi.org/10.1007/s10517-007-0014-1

[219] T. S. Pavlov, L. Sanzhieva, G. E. Samonina, V. I. Sergeev and T. V. Lelekova, "Effect of New Synthetic Anxiolytic Selank on Gastric Wall Blood Flow and Mesenteryc Lymphatic Vessels Contractility in Anesthetized Rats," Rossiüskii Fiziologicheskiu Zhurnal Imeni I.M. Sechenova, Vol. 91, No. 2, 2005, pp. 178-183.

[220] L. A. Liapina, V. E. Pastorova, T. Y. Obergan, G. E. Samonina, I. P. Ashmarin and N. F. Miasoedov, "Comparison of Anticoagulant Effects of Regulatory Proline-Containing Oligopeptides. Specificity of Glyprolines, Semax, and Selank and Potential of Their Practical Application," Biology Bulletin, Vol. 33, No. 2, 2006, pp. 153-161. http://dx.doi.org/10.1134/S1062359006020099 